\title{
UN TEXTO OLVIDADO DE RAFAEL DIESTE, ESCRITO Y PUBLICADO DURANTE LA GUERRA CIVIL ESPAÑOLA ${ }^{1}$
}

Las publicaciones periódicas realizadas durante la guerra civil española, aún hoy día, son conocidas sólo parcialmente. La cantidad de revistas y periódicos impresos en esos años, la diversidad de tirajes y la variedad de formas de distribución fueron tales que es verdaderamente lógico que aún no se conozcan en su totalidad y que, por lo tanto, no se hayan estudiado todas ellas en profundidad. Incluso el conocimiento de la actividad literaria de escritores a los que actualmente se les presta una creciente atención, como es el caso de Antonio Sánchez Barbudo o Rafael Dieste, presenta lagunas de difícil solución. En particular, los últimos meses de la labor desarrollada por estos dos escritores durante la guerra han quedado relativamente olvidados por la falta de datos certeros que los documenten. Llevado adelante en circunstancias mucho más precarias que aquellas en las cuales habían podido dedicarse a la publicación de una de las revistas más conocidas y reconocidas la guerra, Hora de España, el trabajo de Sánchez Barbudo y Dieste en el Ejército del Este es prácticamente una incógnita. Justamente en una publicación dependiente de ese ejército fue publicado, la segunda semana de 1939, el olvidado texto diesteano que ahora presento. La aparición de esta nota firmada, y que trata "Sobre los esperpentos de don Ramón del Valle-Inclán", es doblemente llamativa, ya que la labor de difusión en los periódicos de la guerra, con mucha frecuencia, era anónima, en artículos aparecidos sin mención de la autoría, como puede verse en la gran cantidad

1 Agradezco a James Valender, a quien debemos el hallazgo del texto al que se refieren estas páginas, que me lo presentara y que me indicara su procedencia, así como la gentileza de permitir que me encargue de su difusión. 
de colaboraciones sin firma que se le han atribuido a Dieste en la revista Nova Galiza. Hasta donde sé, esta nota a la que ahora me refiero, es la única suscrita por el autor de las redactadas especialmente para algún periódico del frente.

Como se dijo, es sumamente difícil -incluso, pareciera, para los propios participantes- reconstruir la labor realizada en los últimos meses de 1938, aproximadamente desde agosto en adelante. No es extraño, dadas la creciente precariedad de la vida en zona republicana, la frecuencia de los movimientos en esos meses y, desde ya, la peripecia que en seguida iniciarían muchos en el exilio. En resumen, no es mucho lo que se ha dicho sobre los escritores en el período final de la guerra. Así, por ejemplo, Luis Rei Núñez, biógrafo de Dieste, no especifica en qué momento el autor es movilizado. En A travesía dun século, describe con cierto detenimiento la labor de 1938 en las revistas Hora de España y Nova Galiza, pero el rastro de Dieste se vuelve impreciso entre los últimos meses de ese año y un breve regreso a Barcelona en febrero de 1939: "Malos días os de 1939 para tódolos españois, e máis para os da España republicana, a da derrota. En febreiro, os Dieste, que levaban un tempo separados -desde que Rafael marchara ó frente- vense en Barcelona, onde só seguía Carmen"2. Rei Núñez reconstruye entonces, en retrospectiva, la marcha al frente del autor, pero sin nunca mencionar una fecha precisa:

Sequera para quen eran membros de partidos ou sindicatos as cousas eran máis levaderas. Vascos, cataláns e outras agrupacións, xa políticas xa profesionais, mal que ben ían apañándose entre eles. Os independientes en cambio tiñan un apaño, unha defensa dificilísimos. Por eso Rafael diría a Carmen un día: "Eu iríame cos do Exército do Leste". E por eso a muller contestaría: "Pois vaite" (loc. cit.).

He aquí, entonces, la breve mención que aparece en la biografía sobre el trabajo allí realizado:

Alí, en segunda liña de fogo, e ás ordes do comisariado, que tiña estado inmediatamente antes en Solsona e Manresa, e que agora estaba en Olot, traballa Rafael en funcións de títeres para os soldados e con Barbudo e outros na confección do papel quincenal

2 A travesía dun século. Biografía de Rafael Dieste, $2^{\mathrm{a}}$ ed., Ediciós do Castro, Sada, 1994, p. 99. 
El Combatiente del Este, que el diagrama. Alí estaba tamén Arturo Cuadrado, como comisario do exército, e ainda haberían de ir, para outras tareas, Ramón Gaya, Otero Espasandín e Gil-Albert. O grupo, unido por fortes lazos de amistade, fai o labor encomendado admirablemente, como se da empresa máis querida se tratase, como se Hora de España fose ese papel para sinxelos milicianos. Así, o último número do xornal, que levaron canda eles, é un motivo de orgullo para os impresores, que se sinten magoados por non poder repartilo entre a tropa. ¡Co bonito que saíra! ${ }^{3}$

Pero si la noticia del "papel quincenal" no incluye en este caso por desgracia demasiadas precisiones, tampoco los directamente implicados en su confección han podido reconstruir la historia de esta publicación. Rafael Dieste hará referencia a esos meses en cartas tardías, escritas entre 1973 y 1976, publicadas por primera vez en Testimonios y homenajes, volumen compilado por Manuel Aznar Soler, y más tarde incluidas por Xosé Luis Axeitos en el Epistolario del autor. Serán sin embargo informes muy someros, puesto que las cartas responden a consultas sobre su trabajo en Hora de España o en el II Congreso Internacional de Escritores Antifascistas de 1937. Así, el 25 de septiembre de 1973 escribe desde Rianxo a Francisco Caudet, a raíz de las "Noticias sobre Hora de España (reimpresión alemana)", que este último había publicado en Papeles de Son Armadans":

Muchos aspectos oficiales o administrativos se me escapan ahora, en parte porque en algún momento (última etapa de la guerra) me fui por propia iniciativa al frente, a compartir con Sánchez Barbudo la concepción y redacción de El Combatiente del Este. Antes de eso me había trasladado a Barcelona, para suplir a Castelao como director de la revista Nova Galiza, que se publicaba con el patrocinio económico de la Generalidad. En su Comisariado de Propaganda se hallaba la oficina. Días de muchas bombas, las famosas de "aire líquido" que ensayaron los alemanes sobre Barcelona. Momentos de confusión, de hambre generalizada, sin transportes, etc. Al irme al frente la revista quedó a cargo de Carmen, mi mujer ${ }^{5}$.

3 Op. cit., pp. 99-100. Si bien es cierto que Dieste se había encargado en 1927 de la diagramación de su libro A fiestra valdeira (Tipografía El Eco, Santiago de Compostela), parece poco probable, por la presencia de otros escritores más expertos en el oficio, que se encargara en esta ocasión de la tarea.

4 En el tomo 71, núm. 212, pp. 171-198.

5 Testimonios y homenajes, ed. M. Aznar Soler, Laia, Barcelona, 1981, pp. 30-31. También puede consultarse el texto en Obras completas. Epistolario, ed. X.L. Axeitos, Ediciós do Castro, Sada, 1995, p. 726, carta 498. 
Vuelve a escribirle a Caudet el 10 de enero de 1974, ahora desde La Coruña, y comentando los "Apuntes para la biografía de Hora de España, núm. 23", incluidos en la edición facsímil de este número recuperado ${ }^{6}$. Dice allí Dieste:

Por entonces (no puedo precisar la fecha) me fui con Barbudo a El Combatiente del Este, periódico del frente, dejando Nova Galiza encomendada a Carmen. No tengo muy presente la situación de Gil-Albert en ese momento. En todo caso la Barcelona hambrienta y bombardeada de continuo, la condición y título de "miliciano de la cultura", y la diversidad de recursos oficiales para mantener en la retaguardia a toda persona que prestase un servicio importante (si es que había ya tal retaguardia), dejan bastante al margen lo de los turnos militares?.

Otro texto de Caudet, en este caso la introducción a la antología de Hora de España que publicaría en 1975 (en Ediciones Turner, de Madrid), motiva un nuevo comentario de Dieste -enviado desde Plasencia, el 28 de diciembre de 1974- en que se menciona el período final de la guerra. Repite allí la información que ya había dado: "Yo, mayor que Gil-Albert, me fui bastante pronto al frente desde Barcelona para compartir con Barbudo la redacción y confección de El Combatiente del Este,

6 Verlag Detlev Auvermann, Glashütten im Taunus, 1974, pp. xxi-xxxi.

7 Testimonios y homenajes, pp. 37-38; y Obras completas. Epistolario, pp. 734735, carta 503. Aunque, como dice, Dieste "no puede precisar la fecha", ubica el episodio "por entonces", es decir, inmediatamente después de que Quiroga Pla y María Zambrano conversaron con él sobre la presión para que Hora de España quedase sujeta a una "vigilante participación oficial a través de algún género de enlace, algo -en cuanto a su forma- quizá no madurado todavía” (ibid., p. 37). Una presión no menor pues, como Dieste resume el problema, "Había simplemente que optar entre admitir la vigilancia, o dejar la revista totalmente huérfana de apoyo oficial (entiéndase económico)" (loc. cit.). Este "enlace" tomaría finalmente la forma de "Comité Directivo". Es entonces, después de las primeras conversaciones para establecer ese comité, que Dieste marcha al frente. Ahora bien, este Consejo Directivo (que resultó compuesto por Rafael Alberti, María Zambrano, José María Quiroga Pla y Emilio Prados) aparece por primera vez en el núm. 22, fechado en octubre de 1938. Aunque es probable que el número haya aparecido con posterioridad a ese mes, también es cierto que las conversaciones y los reclamos de un mayor control sobre la publicación se debieron haber producido con bastante antelación respecto de la conformación del Comité, como la misma carta de Dieste sugiere. 
dejando encomendada a Carmen el trabajo de Nova Galiza"8. Una cuarta carta, esta vez a Manuel Aznar Soler (escrita en La Coruña, el 15 de noviembre de 1976), también ofrece los mismos datos: "En los últimos tiempos decidí irme al frente de Aragón para compartir con Sánchez Barbudo la confección y redacción de El Combatiente del Este, y Nova Galiza quedó al cuidado de mi mujer, perfectamente compenetrada con su espíritu y propósitos"9.

Estas son, entonces, todas las menciones del autor sobre su trabajo periodístico luego de dejar Barcelona en 1938. Años después de la aparición primera de estos textos y de la biografía hecha por Rei Núñez, fueron publicados los epistolarios de Rafael Dieste y de Carmen Muñoz. Xosé Luis Axeitos en el primer caso, y Axeitos y Charo Portela en el segundo, incluyen allí cartas que, si bien no permiten resolver con exactitud cuestiones relativas sobre $\mathrm{El}$ Combatiente del Este, al menos dejan precisar un poco más las fechas de movilización del autor. En el Epistolario de Dieste, la última carta de 1938 de la que disponemos está fechada el 24 de junio, momento en el que se encuentra aún en Barcelona. Es una carta a su hermano Eduardo referida al libro Teseo ${ }^{10}$ y sin más que una escueta mención final a la circunstancia: "Ahora tendría que hablarte de España... Sería muy largo. Pero nos entendemos"11. La siguiente carta, dirigida a su esposa Carmen Muñoz y ya escrita fuera de España, es del 9 de febrero de 1939 (es decir exactamente un mes después de la publicación de la nota sobre Valle-Inclán, aparecida el 9 de enero de ese año). Es una breve esquela, escrita "en una carretera, camino de San Cyprien", para ponerse en contacto con su mujer una vez iniciado el exilio ${ }^{12}$.

8 Testimonios y homenajes, p. 43; y Obras completas. Epistolario, p. 747, carta 511 .

9 Testimonios y homenajes, p. 80; y Obras completas. Epistolario, p. 777, carta 524.

10 En la carta menciona por ese solo nombre una de las varias versiones que Eduardo publicó de su recopilación de trabajos sobre literatura. Ésta, que acababa de publicarse bajo el sello de la revista uruguaya que dirigía, es Teseo. Los problemas literarios. Ejemplos del Uruguay y una comedia americana para cine y lectura, de Eduardo y Rafael Dieste, Reuniones de Estudio, Montevideo, 1938.

11 Carta 40, en Obras completas. Epistolario, p. 91.

12 Según anota el editor, está escrita a lápiz y los rasgos y la presentación delatan la lógica urgencia con la que fue escrita: "Queridísima Carmen: / Te escribo estas líneas en una carretera, camino de San Cyprien a diez kilómetros de Perpignan, según nos dicen. La carta de Antonio que va para Ángela da otros detalles. / Procuraré comunicarme con Santullano y Sánchez 
A su vez, las cartas de Carmen Muñoz circunscriben fechas similares. La última de 1938 es poco posterior a la de Rafael Dieste del 24 de junio y ya refiere una salida del autor -aunque no permanente- de Barcelona; está fechada en esa ciudad el 3 de julio y dirigida a Eduardo y Milka (el hermano y la cuñada de Dieste): "Rafael se ha marchado por unos días con Barbudo y empiezo a escribiros en esta tarde del domingo con el propósito de terminar la carta y ponerla seguidamente en el correo" 13 . Es notorio que Dieste se había dirigido, si no al frente, sí por lo menos a una zona de relativo peligro, pues la carta termina volviendo al tema de su ausencia, subrayada por la presencia de algunos compañeros que están con ella, de este modo: "La tarde ha terminado y van volviendo todos a la hora de cenar. Todos menos Rafael, y me sigue pareciendo la casa vacía y extraña. Pero volverá dentro de unos días. Volverá, sí” (ibid., p. 34). Por lo demás, que Dieste habría ido con Sánchez Barbudo a una zona relativamente cercana al frente se desprende también de una mención a este último que hay en la carta, al hablar de la escasez de comida que sufren en la casa en la que viven con Ramón Gaya, Fe -su mujer- y su hija de un año, José Otero Espasandín y Eugenio Granell:

El que nos salva es Barbudo. Viene de vez en cuando a Barcelona y nos trae todo lo que encuentra. El rubio y delicado Antonio Sánchez Barbudo, llega tostado, con las manos sucias, y un saco asperísimo y lleno de polvo a cuestas. Excuso deciros cómo le recibimos. A veces nos trae chocolate y leche condensada, y nos reunimos todos para vaciar el saco y hacer exclamaciones mientras él nos mira con un aire paternal, orgulloso y modesto (ibid., p. 32).

Esta carta, pues, demuestra que ya a principios del mes de julio Dieste estaba comenzando a trabajar con Sánchez Barbudo fuera de Barcelona. No es posible saber, en cambio, cuándo

Ventura (Embajada) y con Supervielle para tener noticias tuyas y pedirle apoyo a fin de hacer valer los pasaportes que nos han dado. Necesitamos dinero o persona que responda. / Está tranquila. Calculo tus fatigas por las que yo paso, pero me duelen más las tuyas. Confío que nos veremos pronto. Muchísimos abrazos de / Rafael" (carta 41, en Obras completas. Epistolario, p. 92). La siguiente la escribirá el 11 de febrero, ya internado en el campo de concentración de Saint Cyprien, desde "hace tres días" (ibid., carta 42).

13 Carta 6, en Epistolario, eds. X.L. Axeitos y C. Portela Yáñez, Ediciós do Castro, Sada, 2005, p. 30. 
partió de la ciudad con carácter más permanente, pues no hay ninguna otra carta de Carmen Muñoz escrita ese año y en ésta señala que "Todos los amigos están movilizados menos Rafael y Mariano" 14 . Y a continuación, describe la situación de los amigos:

Varela es Comisario de Batallón, puesto de mucha responsabilidad que desempeña muy bien. Durante el avance fascista por Aragón, se ha portado magníficamente. Barbudo es Comisario de una Escuela de Oficiales en el frente, con todo éxito. Gil Albert, Plaja y Gaya por temporadas están en el frente y otras veces aquí haciendo los periódicos de las divisiones. Espasandín ingresó voluntario en aviación, pero está aquí en oficinas.

Y cualquier día llamarán a Rafael, porque van a movilizar más quintas, según parece.

El pasaje, en fin, interesa por varios motivos. Por un lado, da testimonio de la labor de muchos de los colaboradores de Hora de España hacia julio de 1938; por otro, muestra que los periódicos del frente se preparaban no sólo en las divisiones a las que pertenecían sino también en Barcelona, como pareciera empezar a hacer el mismo Dieste. Finalmente, sirve para suponer su partida definitiva al Ejército del Este como algo ya inminente para esa fecha.

La siguiente carta de Carmen Muñoz está escrita ya en París, el 15 de febrero de 1939, desde el Hospital de La Pitié, donde se había internado luego de la evacuación para curarse las heridas recibidas durante un bombardeo franquista. La dirige a su esposo, que estaba ya en el campo de concentración de Saint Cyprien. Debió haber ido a Figueras junto con el traslado del gobierno, en su salida de Barcelona -allí, en el Castillo de Figueras, sesiona por última vez en España el Congreso republicano el 1 de febrero de $1939{ }^{15}$ - y debió entonces haber tenido noticias del paso de la columna en la que estaba el grupo de prensa del Ejército del Este, pues comienza el relato de su viaje diciendo: "Al día siguiente de estar vosotros en Figueras pasé la mañana entera en el castillo, esperando a Pla"16. Esta carta, en la que la

14 Loc. cit. Según anotan los editores, se refiere a Mariano Gómez, autor del poema que sirve de prólogo al libro de poemas de Dieste: Rojo farol amante (Juan Pueyo, Madrid, 1933).

15 Véase Fernando Díaz-Plaja, La guerra de España en sus documentos, 7 a ed., Plaza \& Janés, Barcelona, 1972, pp. 574-594.

16 Carta 7, en Epistolario, p. 34. "Pla" es, seguramente, Quiroga Pla, a quien Dieste había tratado durante la época en que hacían Hora de España. 
autora narra su partida, es quizás uno de los documentos privados más emotivos y emocionantes -y sin duda interesantessobre el éxodo de los republicanos hacia Francia. Tiene además en sí la extraña y conmovedora "aura" de haber sido el relato por medio del cual Ramón Gaya, meses después, supo lo que le había ocurrido a su mujer ${ }^{17}$.

17 Fe fue gravemente herida en el mismo bombardeo que afectó a Carmen Muñoz. Ésta última fue quien llevó consigo a la hija del matrimonio Gaya -salvada por su madre, que la protegió cubriéndola con su cuerpo-, mientras Fe era trasladada por unos camilleros a alguna enfermería, donde moriría. Dieste, luego de leer el relato del episodio que hace Carmen, le escribe el 20 de febrero, desde Saint Cyprien: "Tengo bastante esperanza de que Fe esté viva. A Ramón se lo diré todo cuando salgamos del campo de concentración. Antes sería inútil y muy arriesgado. ¡Ojalá se haya salvado Fe!" (carta 44, en Obras completas. Epistolario, p. 95). Y el 23 de febrero: "Lo de Fe me duele. Creo que sólo tú y yo hemos sentido por ahora este dolor. Veré la manera de dulcificar el de Ramón cuando llegue el momento de darle la noticia. Tengo todavía la vaga esperanza de que se haya salvado. Todo lo que tendría que decirte sobre esto, me resisto a escribirlo" (carta 45, op. cit., p. 96). Sin embargo, la esperanza no se verá cumplida. Al salir del campo, ya en Poitiers, el 1 de marzo, Dieste escribe a Carmen: "Cualquier día haré una copia a máquina de tu carta grande, prescindiendo de algún detalle un poco rudo, y se la enviaré a Ramón" (carta 46, op. cit., p. 98). El 11 de marzo le comenta que: "por azar, resultó ser Antonio [Sánchez Barbudo] el que le habló primero, un poco atropelladamente, diciendo muchas cosas, haciendo tal vez la brizna que él necesitaba, y haciéndola a fuerza de multiplicar perfiles. Pienso algunas veces que eso ha sido lo mejor. Y desde luego creo que no hay que puntualizar más de lo que él pida... Como Mme. Bloch ha emprendido investigaciones sobre la suerte de Fe, voy a escribirle a Ramón comunicándoselo y de paso, para fundamentar conjeturas, reconstituiré los hechos principales, sin demasiada violencia y haré las citas convenientes de tu carta" (carta 52, op. cit., p. 108). Finalmente, en la siguiente, del 14 de marzo, dice: "Hoy escribí a Ramón una larguísima carta, seis carillas grandes como esta, incluyendo gran parte de tu doloroso testimonio. Al comenzar a escribir pensaba sólo hacer algunas citas breves de tu carta, buscando acomodar la mía al estado de ánimo que supongo a Ramón actualmente. Pero enseguida tus palabras se me adentraron de nuevo en el alma y me fluían como si fuesen mías y las más oportunas para este momento, para cualquier momento... En suma, que una parte grandísima de tu carta va incluida en la mía, todo lo que se refiere a Fe y Alicia excepto algún detalle que pudiera imponerse a la imaginación por su viveza física y turbar con abusivos derechos la totalidad moral -y física también- del trágico suceso. Procuré orientar la piedad de Ramón hacia la pobrecita Fe, guardando para mí las cosas que a mí me toca dolerme, pero el resultado es que entonces tuve de ti más piedad que nunca y una cosa que hace llorar, qué sé yo, acaso admiración. Sin miedo a vanidad ninguna puedes aceptarla. Admiro tu dolor y lloro tu graciosa fortaleza. Y cada vez es más imposible no estar contigo para que veas 
En fin, la información que puede recabarse de los testimonios personales de Rafael Dieste y su mujer no difiere demasiado de -ni es más detallada que- la que ya recopilaran Manuel Aznar Soler y Claudio Rodríguez Fer en dos trabajos dedicados a presentar la labor periodística del autor: "xa en 1939, cabe anotar a sua vinculación co El Combatiente del Este, revista do Exército do Leste onde colaboraron tamén, entre outros, Sánchez Barbudo e Gaya", anota Aznar Soler ${ }^{18}$. Y Rodríguez Fer dice:

Xa en 1939, Rafael Dieste ingresou, en segunda liña no Exército do Este, onde foi comisario e onde coincidiu con Arturo Cuadrado, Ramón Gaya, Xosé Otero Espasandín, Juan Gil-Albert e Antonio Sánchez Barbudo. Con algúns deles elaborou a folla para soldados, que viña confeccionando Antonio Sánchez Barbudo, El Combatiente del Este, para a que chegou a facer mesmo de diagramador. Mirta Núñez Díaz-Balart examinou con detalle a traxectoria de dito periódico, que, pola súa condición de "Órgano del Comisariado del Ejército del Este", prestou "escasa atención a cultura" fronte á "extensión de los temas políticos-militares"19.

En lo que hace a los demás participantes aludidos, tampoco han narrado con detenimiento su trabajo de entonces. Antonio Sánchez Barbudo, el promotor de que los colaboradores de Hora de España se acercaran a la sección de prensa del Ejército del Este, sólo hace una breve mención retrospectiva al período final de la guerra cuando narra su llegada a México como exiliado:

En los últimos días de la guerra tenía yo a mi cargo la publicación del diario del Ejército del Este. Se hacía el periódico, generalmente, en un pueblo de la retaguardia; pero estábamos en retirada, y desde fines de 1938, los traslados de lugar habían sido cada vez más bruscos y frecuentes. Conmigo estaba Rafael Dieste, y en las

todo esto sin decírtelo. Verás como lo ves y entonces verás todo de golpe, y a Fe también de nuevo, y a mí y a España y todo" (carta 53, op. cit., p. 109).

18 "Dieste e as revistas literarias", A Nosa Cultura (Vigo), 1995, núm. 15, p. 41 (número monográfico: Rafael Dieste, "Era un tempo de entusiasmo...").

19 "As revistas de Rafael Dieste”, en Rafael Dieste. Día das Letras Galegas 1995, coord. X.L. Axeitos, Xunta de Galicia, Santiago de Compostela, 1995, pp. 121-122. El crítico agrega que "El Combatiente del Este foi a última empresa cultural de Rafael Dieste durante a guerra, xa que, ó pouco tempo, desmoronada a resistencia republicana, tería que refuxiarse en Francia, onde, despois das máis tráxicas peripecias, se reencontrou coa súa muller e iniciou o longo percorrido do seu intercontinental exilio" (loc. cit.). Me referiré en breve al trabajo de Mirta Núñez Díaz-Balart que cita Rodríguez Fer. 
últimas semanas, previendo ya el colapso total del frente de Cataluña, se sumaron a nosotros Ramón Gaya y Juan Gil-Albert ${ }^{20}$.

Este “diario" al que se refiere Sánchez Barbudo es, lógicamente, el mismo "papel quincenal” que mencionara Rei Núñez: El Combatiente del Este. Esta oscilación no es extraña, pues -además de la variación posible que impone el recuerdo- no necesariamente el impreso habrá tenido una periodicidad constante. De hecho, Mirta Núñez Díaz-Balart, acaso su lectora más documentada (ha consultado treinta y un números), señala que la edición aragonesa era diaria y la edición catalana semanal. La investigadora establece como fecha posible del primer número el 6 de julio de 1937 y describe el formato de este "Órgano del Comisariado del Ejército del Este”, como rezaba su subtítulo, que era de $52 \times 28.5 \mathrm{~cm}^{21}$. Este último dato no es irrelevante pues no coincide con el "suplemento" -al que ya me referiré- en el que apareció la nota de Dieste, una hoja de $44.5 \times 32.5 \mathrm{~cm}$. El formato de El Combatiente del Este pudo, entonces, haber cambiado, o bien pudo haber sido distinto solamente el de este suplemento. Núñez Díaz-Balart, no obstante, no hace mención de ningún suplemento cultural u hoja dedicada a la literatura que editase el periódico ni, tampoco, hace referencia a Sánchez-Barbudo, Dieste, Gaya o Gil-Albert.

Justamente Gil-Albert, uno de los participantes mencionados por Sánchez-Barbudo -aunque según él de los más tardíos- en la realización del periódico, aporta un dato más. Dice que en el campo de concentración de Saint-Cyprien, al grupo que forma-

20 Ensayos y recuerdos, Laia, Barcelona, 1980, p. 98. El texto, recopilado con el título "El grupo de Hora de España en 1939" es un fragmento de la introducción que Sánchez Barbudo preparó para la edición facsímil de la revista Romance (Verlag Detlev Auvermann, Glashütten im Taunus, 1974). En otro de los "recuerdos" incluidos en el mismo volumen, éste dedicado a "Antonio Machado en los años de la guerra civil", el autor hace también someras referencias a su movilización durante la guerra: "[Antonio Machado] aceptó pronto nuestra propuesta, el ruego de que nos diese colaboración mensualmente para Hora de España... Y a partir de ese día y durante seis meses -hasta junio de 1937, fecha en que habiendo el gobierno llamado a filas a mi quinta, dejé la revista, me presenté y me mandaron a Madrid-fui a verle muchas veces al mismo pueblo [Rocafort]" (ibid., p. 13). El posterior traslado de Sánchez Barbudo, aunque no pueda fecharse con exactitud, parecería ser resultado de la reorganización del Ejército del Este en mayo de 1938, al salir Indalecio Prieto del Ministerio de Defensa.

21 La prensa de guerra en la zona republicana durante la guerra civil española (1936-1939), Ediciones de la Torre, Madrid, 1992, t. 2, p. 1009. 
ba con Ramón Gaya, Arturo Serrano Plaja, Antonio SánchezBarbudo y Rafael Dieste,

se nos unieron un malagueño pacienzudo, que me había ayudado a confeccionar nuestro periódico del frente, Bernabé Fernández Canivell, y que, ni en el frente catalán, en los agrestes parajes donde acampaba el XI cuerpo del Ejército, había descuidado el meticuloso aseo de sus pies, y mi amigo valenciano -alicantino como yo- Juan Miguel Romá, frecuentador de mi casa, y al que volví a encontrar en el revoltijo de la retirada, durante nuestras dos últimas semanas españolas ${ }^{22}$.

El pasaje, que -todo hace suponer- refiere también a $\mathrm{El} \mathrm{Com-}$ batiente del Este, tiene la virtud de permitir radicar el trabajo de los que en su mayoría fueran miembros de Hora de España en un cuerpo del Ejército (que, en efecto, pertenecía al Ejército del Este). Así pues, amén de depender nominalmente del Comisariado de dicho ejército, los encargados de la realización del periódico parecen haber estado movilizados todos en el cuerpo XI. En el mismo sentido apuntan los datos que se pueden recabar sobre un participante -y acaso uno de los más importantesque hasta ahora no ha sido mencionado, Manuel Altolaguirre. En sus memorias, el poeta malagueño cuenta que

22 Memorabilia, seguido de "Drama patrio" y "Los dias están contados", Tusquets, Barcelona, 2004, p. 186. En relación con el trabajo del malagueño en ese período, puede consultarse una carta inédita de Andrés Iduarte -reproducida por María José Jiménez Tomé-, escrita en Nueva York el 8 de junio de 1939, en la que Iduarte acusa recibo de Granada de las letras y de las armas y varios libros y, a la vez, solicita a Fernández-Canivell que le envíe las ediciones del Comisariado del Ejército del Este ("El impresor Manuel Altolaguirre durante la guerra civil española [1936-1939]", en Viaje a las islas invitadas. Manuel Altolaguirre [1905-1959], ed. J. Valender, Sociedad Estatal de Conmemoraciones Culturales-Residencia de Estudiantes, Madrid, 2005, p. 495). Fernández-Canivell fue quien conservó, desde los inicios de la guerra, manuscritos originales de varios libros de Emilio Prados: Andando, andando por el mundo, La voz cautiva y La tierra que no alienta (véase la introducción de Carlos Blanco Aguinaga y Antonio Carreira a su ed. de Emilio Prados, Poesías completas, Aguilar, México, 1975, t. 1, pp. lxiv-lxv; así como también el núm. 6 de la revista Puertaoscura [1988], que incluye un "Homenaje de Bernabé Fernández-Canivell a Emilio Prados"). Por su parte, Concha Méndez recuerda a Fernández-Canivell durante la guerra, tanto en los primeros días en Madrid como en los últimos, en Cataluña (PALOMA Ulacia Altolaguirre, Concha Méndez. Memorias habladas, memorias armadas, Mondadori, Madrid, 1990, pp. 100 y 104). 
En el XI Cuerpo del Ejército, terminé desempeñando de nuevo mi oficio de impresor... imprimíamos un boletín diario, que acompañábamos semanalmente de una hoja literaria titulada Los Lunes del Combatiente. En dicha publicación aparecían romances y canciones tradicionales, antologías de poetas contemporáneos y alguna que otra colaboración inédita ${ }^{23}$.

Altolaguirre, entonces, recuerda la radicación del grupo de redactores de $\mathrm{El}$ Combatiente del Este, órgano del Comisariado del Ejército del Este, en el XI Cuerpo ${ }^{24}$ y, además, a diferen-

23 El caballo griego, cap. 27, en Obras completas, ed. J. Valender, Istmo, Madrid, 1986, t. 1, pp. 107-108.

24 La pertenencia de la imprenta al XI Cuerpo la corroboran las memorias de Altolaguirre en el recuerdo que hace de Francisco Galán, su jefe. Asimismo, a Galán lo menciona, en relación con ese cuerpo, Vicente GuARNER, al describir la reorganización de fines de mayo de 1938 de los ejércitos de Cataluña (el del Este y el del Ebro): "El general Hernández Sarabia, no comunista, iba a mandar estos ejércitos. Su comisario era Ángel Roldán, de la C.N.T. El ejército del Este iba a ser mandado por el coronel Perea, no comunista, pero con un jefe de Estado Mayor comunista, coronel Carvajal, y un comisario, Mantecón, del mismo partido, con dos Cuerpos de ejército, XI y XVIII, mandados por los comunistas Galán y del Barrio, y el X por Jover, de la C.N.T. El predominio comunista era evidente en este Ejército. El otro Ejército, completamente comunista, iba a ser mandado por Modesto, con Delaje como comisario. Sus Cuerpos de ejército V, XII y XV serían mandados por los comunistas Líster, Vega y Tagüeña, encontrándose en formación toda la gran unidad en junio de 1938" (Cataluña en la guerra de España [19361939], G. del Toro, Madrid, 1975, p. 334). También Jesús Pérez Salas Salas -quien fuera durante la guerra Subsecretario del Ejército de la República, Comisario General de Somatenes del Gobierno de la Generalidad de Cataluña, Jefe Superior de Policía de Barcelona y Jefe de Cuerpo de Ejército, de División y de Columna- hace referencia a esta reorganización, posterior a la salida de Prieto del Ministerio de Defensa: "Al terminar esa reorganización, el Ejército de Cataluña, que era sin duda el más interesante para ellos, quedaba en la siguiente forma: Dos Ejércitos, uno llamado del Ebro, era mandado por Modesto, comunista, con todos sus jefes de C.D.E. División y Brigada, pertenecientes al mismo partido; el otro, llamado del Este, estaba mandado por Perea, militar profesional procedente de la escala de reserva y retirado por la ley Azaña al advenimiento de la República, quien no se hallaba afiliado al partido comunista, pero a este partido pertenecían su jefe de E.M. y su comisario. Sabido es por todos que, en este Ejército, se imponían las consignas del «partido». De los tres C.D.E. de que se componía, uno lo mandaba, como ya hemos dicho, Trigueros, quien fue sustituido poco después por Jover, jefe de milicias de la C.N.T.; otro tenía por jefe a Galán, de sobra conocido por nosotros, y, el tercero, estaba mandado por Del Barrio, también citado en páginas anteriores. Total, dos comunistas y uno de la C.N.T. Como jefes profesionales en mando superiores sólo quedaron en Cataluña 
cia de los otros autores citados -Dieste, Sánchez Barbudo y GilAlbert- recuerda su "suplemento cultural", por llamarlo así, en el que se encuentra la nota firmada por Dieste. En efecto, ésta fue impresa en una publicación que, con el subtítulo "hoja semanal de literatura", se llamó Los Lunes de El Combatiente. Sobre ella, casi nada se ha escrito. Una de las escasísimas menciones aparece en el libro de Rafael Osuna dedicado a Las revistas españolas entre dos dictaduras: 1931-1939. Señala allí el crítico que tanto sobre ésta como sobre otras dos publicaciones de la guerra, Los Poetas del Mundo defienden al Pueblo Españoly Granada de las Letras y de las Armas, "nuestra información es muy escasa" y dice: "Otra de estas raras revistas se llamó Los Lunes del Combatiente [sic], que era un suplemento literario que Manuel Altolaguirre agregaba a un boletín militar de cuya impresión estaba a cargo"25.

No es casual que Osuna la traiga a colación al referirse a las colaboraciones editoriales de Altolaguirre con Neruda. Por las mismas fechas en que fueron impresos los últimos números de Los Lunes de El Combatiente, también se dedicó Altolaguirre a la

Perea y Galán, cuyas características de cultura profesional han quedado ya expuestas" (Guerra en España [1936 a 1939]. Bosquejo del problema militar español; de las causas de la guerra y del desarrollo de la misma, s.e., México, 1947, p. 188). Desde su mirada de militar profesional, Pérez Salas dedica bastante espacio a criticar el trato de los jefes comunistas -ejemplo de los cuales es Galán- a sus subordinados, tan distinto a los oficiales de carrera, incluso rusos: "Yo tenía la idea de que en el ejército ruso existía mucho más acentuada esta camaradería, por lo que quedé sorprendido al ver que, al llegar aquellos oficiales soviéticos al comedor, todos se colocaron de pie ante sus asientos, en espera de la invitación del comandante, para que se sentaran. Recuerdo que no tomaban café, por lo que abandonaban la mesa antes que nosotros; pero de ninguna manera lo hacían sin que el jefe les indicara con un gesto que podían marcharse. No sé si se tuteaban entre sí, pues desconozco el idioma ruso, pero con lo que vi quedé bien enterado de la rígida disciplina que observaban. ¿Por qué nuestros comunistas no copiaron esto también? ¡Qué diferencia con lo que hacía Galán, que sólo era pura chabacanería!” (ibid., p. 193). Muy distinta es la percepción de Altolaguirre: "A los pocos días fui destinado al XI Cuerpo del Ejército, cuyo teniente coronel, un hermano del héroe de Jaca, era mi amigo Francisco Galán, cuyas dotes de mando y enérgico carácter contrastaban con su bondadosa camaradería hacia los soldados, cuando tal actitud no significaba relajamiento de la disciplina ni pérdida de su austera personalidad" (El caballo griego, ed. cit., p. 105).

25 Las revistas españolas entre dos dictaduras: 1931-1939, Pre-Textos, Valencia, 1986, p. 141. Osuna culmina su relación de la hoja con una cita del pasaje de El caballo griego ya referido: "Según diría el propio impresor, «en dicha publicación aparecían romances y canciones tradicionales, antologías de poetas contemporáneos y alguna que otra colaboración inédita»" (loc. cit.). 
impresión de algunos libros que fueron publicados con el sello "Ediciones Literarias del Comisariado del Ejército del Este". Uno de ellos fue España en el corazón. Himno a las glorias del pueblo en la guerra, poemario de Pablo Neruda del que el Comisariado haría dos ediciones en el breve lapso de dos meses. El pie de imprenta de la segunda edición es del 10 de enero de 1939, apenas un día después del último número conocido de Los Lunes... ${ }^{26}$.

Julio Vélez y Antonio Merino, que han editado el facsímil de otro de los volúmenes impresos por las "Ediciones literarias del Comisariado", anotan que

En 1938 el Monasterio de Montserrat se convirtió por orden del Gobierno republicano de la Generalitat en Hospital de Sangre, y su imprenta, creada por Rosembach y Luscher, discípulos directos de Gutenberg, quedó paralizada, volviendo a funcionar en el mismo año bajo la dirección de Altolaguirre. En esta imprenta se imprimieron España, aparta de mí este cáliz, España en el corazón y el Cancionero menor para combatientes 27 .

La imprenta del Comisariado, en efecto, estuvo en esos días en el Monasterio de Montserrat (de donde puede inferirse que

26 Puede consultarse el facsímil de un ejemplar de la que fue la $2^{\mathrm{a}} \mathrm{ed}$. de España en el corazón realizada por las Ediciones Literarias del Comisariado del Ejército del Este en la Biblioteca Virtual Miguel de Cervantes. La primera edición a cargo del mismo "sello editorial" - de la que también disponemos hoy una ed. facsímil, acompañada de un estudio de James Valender: Pablo Neruda y Manuel Altolaguirre. Notas sobre la primera edición española de "España en el corazón" (Diputación de Córdoba-Renacimiento-Centro Cultural de la Generación del 27, 2004)- había aparecido, con una tirada de quinientos ejemplares (la segunda fue de mil quinientos), el 7 de noviembre de 1938. Carles Gerhard, por aquel entonces Comisario de la Generalitat en Montserrat, quien cree perdida la segunda edición, dice sobre la publicación del poemario de Neruda: "La primera edición de España en el corazón, en noviembre de 1938, de corta tirada, se repartió entre las autoridades políticas y militares de la República y la segunda edición, en enero de 1939, no alcanzó a encuadernarse, o sea las páginas del libro quedaron en rama. La imprenta republicana terminó sus funciones con la llegada de los soldados franquistas al Monasterio a principios de febrero de 1939. Los nacionales destruyeron los libros republicanos, entre ellos la segunda edición de España en el corazón" (Comissari de la Generalitat a Montserrat: 1936-1939, Abadía de Montserrat, Barcelona, 1982, apud M.J. Jiménez Tomé, art. cit., p. 488).

27 Julio Vélez y Antonio Merino, España en César Vallejo, t. 1: Poesía, Fundamentos, Madrid, 1984, p. 146. El colofón del libro de César Vallejo indica una fecha diez días posterior a la que se registra en el de Neruda: 20 de enero de 1939. No he podido consultar la edición del Cancionero menor para combatientes, de Emilio Prados. 
la impresión del número 9 de Los Lunes... debió haber sido hecha en el mismo lugar). Así también lo afirma el propio Altolaguirre:

Mi querido José Antonio: El libro de Pablo lo imprimí en el Monasterio de Montserrat, donde los frailes tenían uno de los mejores talleres de Cataluña. Pensé hacerlo en una máquina de pedal, que llevé conmigo al mismo frente para editar el Boletín Diario del XI Cuerpo de Ejército, la hoja literaria Granada de las Letras y de las Armas y algunos folletos y propaganda.

No teníamos papel para tales trabajos, y como mi jefe, el teniente coronel Paco Galán, no quería enviarme a las trincheras, yo quise ser útil trabajando en la imprenta. Nos enteramos que cerca del frente, en Orpi, había una fábrica de papel abandonada y decidimos ponerla a funcionar. Fue el comisario jefe Juan Ignacio Mantecón y otro querido amigo, Arturo Cuadrado, quienes organizaron la producción y facilitaron todos los elementos ${ }^{28}$.

Así pues, a fines de 1938 y de la guerra, el XI Cuerpo del Ejército del Este, y su Comisariado, contaban con una sección de propaganda en la que participaban, entre otros, Manuel Altolaguirre, Antonio Sánchez Barbudo, Rafael Dieste, Juan GilAlbert, Ramón Gaya, Arturo Cuadrado -es decir, buena parte de los redactores de Hora de España- y publicaban tres importantes libros de poesía y una hoja semanal de literatura ${ }^{29}$. Esta

28 Carta de Manuel Altolaguirre a José Antonio Fernández de Castro, en Pablo Neruda, Obras completas, $3^{\mathrm{a}}$ ed. aum., Losada, Buenos Aires, 1968, t. 2, pp. 1310-1311, apud J. Vélez y A. Merino, op. cit., pp. 146-147 (con ligeras variantes, también reproduce la carta, fechada en La Habana en noviembre de 1941, M.J. Jiménez Tomé en su art. cit., p. 492; allí se indica que fue primero publicada por Aldunate Phillips en su edición de PABLO Neruda, Selección, Nacimiento, Santiago de Chile, 1943, pp. 321-322). Es ésta la única mención que conozco de Arturo Cuadrado (quien sería luego un importante promotor de la labor editorial republicana en Buenos Aires) como participante de la sección de propaganda del Ejército del Este.

29 A los nombres ya citados, José Ignacio Mantecón, comisario general del Ejército del Este y director de sus Ediciones Literarias durante los últimos meses de 1938, suma los de Emilio Prados y Concha Méndez. En un texto inédito sobre Pablo Neruda escrito en 1973 dice: "Editada por primera vez en Chile, España en el corazón llegó a España y Manuel Altolaguirre, que amaba tanto la poesía como los tórculos de la prensas trajo al Comisariado del Ejército del Este un ejemplar. Altolaguirre, con Sánchez Barbudo, Ramón Gaya, Gil-Albert, Dieste, Emilio Prados y Concha Méndez formaban parte de la unidad encargada de la propaganda en ese Ejército. Estaban sometidos a la tarea de redactar, imprimir y repartir los periódicos de las unidades y 
labor cultural se sumó -o, acaso, hacia finales de la guerra, buscó dar una nueva dirección- a una importante difusión política que El Combatiente del Este ya realizaba desde antes. En efecto, el trabajo de prensa del Comisariado debió de haber sido abundante y notorio. En un libro publicado en México en 1947, sobre todo destinado a refutar el análisis de la guerra que había hecho el general Vicente Rojo, el coronel Jesús Pérez Salas menciona la propaganda del XI Cuerpo e, implícitamente, muestra que debió haberle impresionado por su cantidad, pues se refiere a "Galán, que mandaba uno de los cuerpos del ejército" y a "su propaganda política que era tan intensa dentro de esa gran unidad" 30 . Sea como sea, Los Lunes de El Combatiente y los tres

del Ejército, así como proclamas y a elaborar determinados programas de radio", citado por Marco Aurelio Torres H. Mantecón, "Poetas en guerra: Neruda, Prados y Vallejo en un curioso sello editorial: las «Ediciones Literarias del Comisariado del Ejército del Este» (1938-1939)", comunicación al Congreso Internacional "La guerra civil española, 1936-1939", organizado por la Sociedad Estatal de Conmemoraciones Culturales y el Ministerio de Cultura, realizado en Madrid del 27 al 29 de noviembre de 2006 (puede consultarse una versión electrónica de esta ponencia en el sitio http://www. secc.es/ponencias.cfm). James Valender me señala que es ésta la única mención del trabajo de Concha Méndez en la unidad de propaganda del Comisariado. En efecto, en sus "memorias habladas", Méndez recuerda de modo somero su viaje desde París a Barcelona, momento a partir del cual debió producirse la colaboración: "Viajé a Barcelona, porque Manolo quería ver a la niña... El gobierno de Cataluña nos presta el Monasterio de San Benet... Al principio, Manolo estuvo conmigo; pero después volvió al frente de batalla a continuar su labor como impresor. Entonces yo escribí un grupo de canciones en seguidillas, que los soldados del frente de Aragón cantaban con la guitarra; firmaba con seudónimo, porque aquellas letras eran tan tremendas que, de haber revelado mi nombre, hubiese puesto en peligro mi vida. Manolo me pidió que fuéramos a verlo; en Barcelona la Cruz Roja nos fue a buscar para llevarnos al frente. Fue una cosa tremenda; no pasaba un solo momento sin que se escucharan cañonazos, tiros y todos los ruidos de la guerra. Nos hospedamos en una casa bombardeada, con una escalerilla que subía al único cuarto que quedaba en pie. Allí tenía Manolo una pequeña imprenta y me contó que el papel con el que imprimían estaba hecho con los uniformes de los soldados muertos" (P. Ulacia Altolaguirre, Concha Méndez. Memorias..., pp. 103-104).

30 Guerra en España (1936 a 1939). Bosquejo..., p. 207. Pérez Salas menciona esa propaganda al referir el nombramiento de su hermano Joaquín como jefe del Ejército de Andalucía; dice que el cargo no fue aceptado ya que, siendo militar de carrera, entraría, según el autor, en conflicto con los comandantes comunistas: “¿Qué se pretendía con ese nombramiento? ¿Originar una nueva destitución al primer choque que inevitablemente tenía que producirse con Galán, que mandaba uno de los cuerpos del ejército, al tratar de cortar su propaganda política que era tan intensa dentro de esa gran 
poemarios editados por las Ediciones Literarias del Comisariado son el testimonio último de la preocupación por la difusión de la cultura que caracterizó a la República en períodos de paz y de guerra ${ }^{31}$.

En la actualidad, hasta donde sé, sólo se encuentran ejemplares de cuatro números de Los Lunes de El Combatiente, todos en Barcelona. El Arxiu Històric de la Ciutat (dependiente del Institut de Cultura del Ajuntament de Barcelona) dispone del primer número, del 14 de noviembre de 1938, y la Biblioteca de Catalunya cuenta con los números 7, 8 y 9, fechados respectivamente el 26 de diciembre de 1938, el 2 de enero de 1939 y el 9 de enero de 193932 . Vale decir, más allá de la posibilidad -remota, dada la fecha de publicación del número noveno- de que haya podido haber números posteriores al 9 de enero, que se encuentran perdidos los correspondientes a los días 21 y 28 de noviembre y 5,12 y 19 de diciembre.

En la última de las entregas de esta hoja semanal de literatura, pues, se encuentra impreso un escrito hoy en día desconocido de Rafael Dieste. Se trata de "Sobre los esperpentos de don Ramón del Valle-Inclán”. La presencia de esta nota firmada por el autor tiene un valor histórico insoslayable: permite conocer mejor su labor periodística durante un período del que poco se sabe y habla a las claras de la posibilidad de que haya más textos desconocidos. De hecho, Núñez Díaz-Balart, en su trabajo ya citado, menciona la aparición de un texto de Dieste en

unidad? Es seguro que mi hermano no hubiera permitido la continuación de ese jefe en mando de tanta importancia y para el que era de todos sabido no reunía condiciones". No es claro en qué medida el jefe del Ejército de Andalucía podría tener capacidad para destituir a Galán que, según Pérez Salas, ya entonces (mayo o junio de 1938), era jefe de un cuerpo del Ejército del Este. El libro de Vicente Rojo con el que Pérez Salas a menudo discute y que con frecuencia busca refutar es ¡Alerta a los pueblos! Estudio político-militar del período final de la guerra española (Aniceto López, Buenos Aires, 1939).

31 Así también lo entiende, por aquellas mismas fechas, MARía ZAMBRANO; en su reseña de "Las ediciones del Ejército del Este", impresa -hacia enero de 1939- en el último número de Hora de España, dice que la publicación de los tres volúmenes de poesía "no deja de ser una manifestación más del verdadero espíritu que anima a nuestra lucha, pues nunca la poesía ha estado tan unida a la guerra" (Hora de España, noviembre de 1938, núm. 23, p. 72; y Senderos: los intelectuales en el drama de España-La tumba de Antígona, Anthropos, Barcelona, 1986, p. 182).

32 Agradezco la amabilidad de Teresa Llorens, del Arxiu Històric de la Ciutat, en la Casa de l'Ardiaca, así como la gentil colaboración del personal de la Biblioteca de Catalunya, que me permitieron consultar el material. 
el semanario La Armada. Órgano oficial de los marinos de la República: "Durante un tiempo se publica como folletín la obra de Rafael Dieste, «Mascaradas en un acto», al mismo tiempo que se empiezan a publicar colaboraciones de los «compañeros del Norte» a los que dedican editoriales cuando comienza la ofensiva"33. Ha de tratarse del "Nuevo retablo de las maravillas", subtitulado "Mascarada en un acto" -y acaso el plural "Mascaradas" obedezca justamente a su publicación como folletín. La investigadora no menciona la fecha en que la obra se imprime en $L a$ Armada, pero, en todo caso, el primero de los números que ha consultado, el 15, es del 5 de junio de 1937 (el periódico había iniciado su publicación el 27 de febrero de 1937 y llegaría al número 105, del 25 de febrero de 1939) y la obra de teatro diesteana había aparecido originalmente en el primer número de Hora de España (pp. 65-79) de enero de 1937, lo cual refuerza la idea de que se trata de una reimpresión ${ }^{34}$.

En cuanto a la nota "Sobre los esperpentos de don Ramón del Valle-Inclán”, es a tal punto desconocida que no aparece ni siquiera mencionada en las bibliografías más exhaustivas de la obra de Rafael Dieste ${ }^{35}$. No se trata, desde luego, de un pasa-

33 La prensa de guerra en la zona republicana..., p. 495.

34 También durante la guerra esta obra fue publicada en Londres, en una traducción al inglés realizada por A.L. LLOYD, con el título "The new spectacle of wonders" (New Writing, Autumn 1937, núm. 4, pp. 232-244). La versión original castellana puede consultarse en RAFAel Dieste, Teatro, ed. M. Aznar Soler, Laia, Barcelona, 1981, t. 2, pp. 73-94; y en Guerra literaria, ed. C. Rodríguez Fer, Ediciós do Castro, Sada, 1991, pp. 47-59.

35 El más importante trabajo de ordenación bibliográfica de la obra de Rafael Dieste ha sido realizado por Xosé Luis Axeitos. Véanse, entre muchas otras, sus "Cronoloxía e bibliografía de Rafael Dieste", en Rafael Dieste. Un creador total (Galaxia, Vigo, 1995, pp. 119-184); "O laberinto bibliográfico", en Rafael Dieste. O amo das xeometrías, coord. X.L. Axeitos (suplemento especial de la Revista das Letras, O Correo Galego [Santiago de Compostela], 2 de febreiro de 1995, 22-23); "Bibliografía”, A Nosa Cultura (marzo de 1995, núm. 15, 97-105); "Rafael Dieste: Bibliografía básica”, en Rafael Dieste. Día das Letras Galegas 1995, coord. X.L. Axeitos (Xunta de Galicia, Santiago de Compostela, 1995, pp. 13-23) y Rafael Dieste. Bibliografía e cronoloxía (Universidade, Santiago de Compostela, 1995). Pueden también consultarse: Arturo Casas, "Bibliografía primaria", en Rafael Dieste e a súa obra literaria en galego (Galaxia, Vigo, 1994, pp. 325-331), "Rafael Dieste: bibliografía", Boletín Galego de Literatura (novembro de 1994, núm. 12, 129-167) y "Bibliografía”, en La teoría estética, teatral y literaria de Rafael Dieste (Universidade de Santiago de Compostela-Deputación de A Coruña, Santiago de Compostela, 1997, pp. 631-642); Xosé Ramón Freixeiro Mato, "Bibliografía”, en Rafael Dieste. Vida, personalidade e obra (Laiovento, Santiago de Compostela, 1995, 
je de algún otro texto de los que el autor rianxeiro escribió sobre la obra de Ramón del Valle-Inclán. Los textos conocidos de Dieste en los que se refirió a Valle-Inclán son tres: una breve nota publicada en la "revista epistolar y de ensayos" P.A.N. ("Valle Inclán, premio Nobel", núm. 3, marzo de 1935, pp. 4546), un artículo aparecido en Hora de España ("Hispanidad de Valle-Inclán", núm. 5, mayo de 1937, pp. 27-34) ${ }^{36}$ y la glosa de la conferencia "Una semblanza espiritual de Valle Inclán" (leída en el Paraninfo de la Universidad de Montevideo) resumida por Esther de Cáceres para el diario montevideano El País (4 de noviembre de 1948), que fue recopilada en el libro de Dieste editado por Manuel Aznar Soler poco después de la muerte del autor: Testimonios y homenajes (pp. 209-216) ${ }^{37}$.

Ahora bien, el escrito de Dieste de 1939 no es el único del número dedicado al autor de Luces de bohemia. La novena entrega de Los Lunes de El Combatiente es casi en su totalidad un homenaje a Ramón del Valle-Inclán, que había muerto el 5 de enero

pp. 335-357); Estelle Irizarry, "Selected bibliography", en Rafael Dieste (G. K. Hall, Boston, 1979, pp. 177-181) y "Bibliografía”, en La creación literaria de Rafael Dieste (Ediciós do Castro, Sada, 1980, pp. 279-287); CARMEN MuÑoz, "Bibliografía", Grial (outubro-decembro de 1982, núm. 78, 490-500) y, sin firma, "Bibliografía de y sobre Rafael Dieste", Documentos A (enero de 1991, núm. 1, 151-157); Manuel F. Vieites, "Bibliografía básica de e sobre Rafael Dieste", en Rafael Dieste: heterodoxia e paixón creadora, de V.F. Freixanes et al. (Xerais, Vigo, 1995, pp. 105-117).

36 Además de aparecer, lógicamente, en las sucesivas ediciones facsímiles de Hora de España, el texto fue reproducido en Testimonios y homenajes (pp. 121-131), en el número que la revista Documentos A dedicó al autor (cit. supra, n. 35, 202-204) y en la compilación, preparada por Claudio RodríGUEZ FER, de escritos de Dieste publicados durante la guerra civil (Guerra literaria, pp. 73-79). Fue también parcialmente traducido al gallego, con el título "Valle Inclán tiña mil anos", en el número dedicado a Dieste por la revista Grial (Vigo), outubro-decembro de 1982, núm. 78, 451-452.

37 Hay en verdad un cuarto escrito - primero en orden cronológicoen que Dieste parece haberse dedicado a la obra de Valle-Inclán. El trabajo, titulado "Teoría del esperpento", fue publicado en el periódico Galicia (Vigo), el 3 de marzo de 1925. No he podido consultar este texto, ya que los nueve volúmenes de la ed. facsímil de Galicia. Diario de Vigo (publicada en 1990 por Ediciós do Castro) sólo reproducen el periódico hasta su número del 30 de septiembre de 1924. Euloxio R. Ruibal, que se refiere muy breve y lateralmente al artículo diesteano ("Ecos valleinclanianos en Don Frontán", en Tentativas sobre Dieste, coord. A. Casas, Sotelo Blanco, Santiago de Compostela, 1995, p. 150, n. 4), cita la dedicatoria que lo encabeza: "A don Ramón del Valle-Inclán, que sabrá perdonarnos la intrusión en sus dominios, implícita en el título de este esquema, si no tenemos la fortuna de acertar" (loc. cit.). 
de 1936; de ahí el título con el que se incluye, en primer lugar, el fragmento de un texto de Manuel Azaña: "A Valle-Inclán en el tercer aniversario de su muerte". El resto de la primera página lo ocupa la nota de Rafael Dieste, ilustrada con una viñeta, "Visión fantasmona de don Ramón del Valle-Inclán en el café”, firmada por Ramón Gaya en 1939. Al dorso, además de la reproducción del relato "iMalpocado!”, bajo el epígrafe "Un cuento de Valle-Inclán”, están impresos -ya fuera del homenaje al escritor gallego- dos romances: "Romance del rey moro que perdió a Albama" y "El moro Abenámar", el segundo fechado en 1431, y ambos bajo el título general "De nuestro romancero" 38 .

El cuento de Valle-Inclán, que desde 1904 fue integrado por el autor en los capítulos 1 y 3 de la cuarta estancia de Flor de santidad. Historia milenaria ${ }^{39}-\mathrm{y}$, por tanto, reimpreso de esa forma en su Opera Omnia ${ }^{40}$-, debió ser tomado de alguna de sus varias reimpresiones como cuento independiente, incluso con posterioridad a la refundición; acaso de la más tardía, en Flores de almendro ${ }^{41}$, volumen que llegó a preparar, pero no a terminar, Valle-Inclán antes de su muerte ${ }^{42}$. El ambiente gallego del cuento, la nota firmada que aparece en el mismo número, hacen creer que pudo haber sido Dieste quien lo seleccionara para la publicación.

El texto de Manuel Azaña, aunque la reimpresión no lo aclara, es un breve pasaje de un artículo mucho más extenso, que había aparecido originalmente en el número dedicado a Valle-

38 La sección "De nuestro romancero" ya se encontraba en los números 7 y 8 de la hoja -aunque no aparece en el primero. En los números 8 y 9, los primeros romances incluidos traen una nota aclaratoria; en la del número 8, tiene claramente la intención de reponer el contexto del poema; la del número 9, en cambio, parece no descartar la intención moralizante ni desaprovechar las resonancias que la guerra del siglo Xv pudiera tener en 1939: "Declinante ya el poderío árabe en España, cuando sus reinos se reducen a algunas hermosas ciudades andaluzas, la estrella favorable a los cristianos hace posible la floración de los romances llamados fronterizos, exentos de odio, impregnados a veces de una caballeresca conmiseración hacia los vencidos, de los cuales imitan la galanura, y aún otras veces su amanerado preciosismo".

39 Imprenta de Antonio Marzo, Madrid.

40 T. 2, Perlado, Páez y Cía., Madrid, 1913.

41 Librería Bergua-Imprenta de Sáez Hermanos, Madrid, 1936, pp. 221-224.

42 De las veintidós impresiones del cuento en vida de Valle-Inclán que refiere Javier Serrano Alonso (Los cuentos de Valle-Inclán. Estrategia de escritura y genética textual, Universidade de Santiago de Compostela, 1996, pp. 26-27), nueve son posteriores a 1913, año de la primera edición de las obras completas. 
Inclán de la revista La Pluma, en enero de 1923: "El secreto de Valle-Inclán”. En el fragmento que reproduce Los Lunes..., se lee:

Hilvano con un rasgo común las variantes de su persona que Valle-Inclán ha pensado y estilizado, y obtengo un tipo complejo, quijotesco si fuese menos precavido, dominante si tuviese menos orgullo. El personaje a quien Valle-Inclán ha transmitido su nombre y su figura, es un semidiós movido por el afán de la justicia absoluta. Sus odios, su crueldad verbal, su intransigencia, pueden invocar, en el origen, un motivo de interés público aceptable. Es un héroe desprovisto de misericordia que ha tirado muchas piedras porque estaba libre de pecado. Se sitúa, naturalmente, en la extrema oposición. Es una picota de lo mediocre y de lo malo; un anticipo del juicio final para los chirles, los hipócritas, los vividores; es un hurón que vocifera sus despegos. Pero esa justicia, que ama tanto, no la aprende en otros ni menos la recibe de una ley exterior. Valle-Inclán es el hombre de la ley propia que desprecia la jerarquía social y legal porque está corrompida. Vagando por tierras toledanas entró con unos amigos en la posada Olías del Rey. Sobrevino un posadero, a quien por ciertos dimes y diretes amenazó con unos palos: -¿Palos a mí? ¿De qué manera? -¡Así!-. Y le dio unos cuantos estacazos -¡Dios mío!- exclamó la posadera¡Dios mío! ¡Pegar al alcalde!! El acento bufonesco con que remeda el grito de la posadera lleva todavía una segunda intención, enteramente añadida por Valle: subrayar su señorial despotismo, las turbulencias con que arrolla al representante de la ley. "¿Alcalditos a mí? ¿Y a tales horas?”, podría exclamar. No soporta alcaldes ni alcaldesas, llámense como quiera. De grado respeta el capricho ajeno; pero necesitará ir en la vida por una vereda muy ancha para sentirse holgado. En qué partes entran a formar su ley propia la herencia, unas siluetas históricas, arquetipos poéticos, y un mesianismo vago, que suele andar por aquellos rincones mal conocidos de su invierno, es menos importante que nombrar sus dos fundamentos: la independencia personal y el pundonor. No obligarse a doblar la cabeza ante nadie, sostener la fama y el crédito a todo evento; tales son, a mi parecer, las causas de muchas abstenciones y de algunas intromisiones de Valle, a costa de su bienestar y su comodidad, en tiempos; arriesgando locamente la vida, las raras veces que de ello ha sido caso ${ }^{43}$.

43 Transcribo el texto según aparece en Los Lunes..., sin la separación de párrafos del original, y corrigiendo algunas erratas (la más importante de las cuales es el reemplazo de "remeda" [el grito de la posadera] por "resuena") pero no las variantes de puntuación. Dos cambios sobresalen en la reimpresión de Los Lunes...: allí donde decía "clamó la posadera”, aquí se lee "exclamó la posadera"; poco después, aparece aquí en plural lo que 
Quizás resultó a los miembros del Comisariado más fácil conseguir el texto de la revista La Pluma que otro más reciente -y probablemente más recordado en ese momento- que el presidente de la República había escrito con motivo de la muerte de Valle-Inclán: "En la muerte de don Ramón...", publicado el 7 de enero de 1936 en Política ${ }^{44}$. De todas formas, es cierto que esta última evocación del escritor muerto es un escrito breve, sin más intención que el homenaje póstumo, mientras que la nota de La Pluma se propone como un estudio más amplio, sobre la relación entre la persona y la obra de Valle-Inclán (el pasaje seleccionado, de hecho, es aquel en el que se inicia una suerte de recapitulación de los rasgos que se han ido mencionando, e inmediatamente anterior a la caracterización del escritor como fascinado por ser "un gran general", sección que acaso no se considerara apropiada en 1939, ya que incluso se narra una anécdota que ocurre cuando se dirige a presenciar un fusilamiento). También es posible que el texto haya sido entregado o indicado por Manuel Azaña al Comisario del Ejército del Este. En su diario, Azaña anota una visita de José Ignacio Mantecón el 24 de noviembre de 1938:

Mantecón, que fue gobernador general de Aragón hasta el desastre de abril, y ahora comisario general del Ejército del Este. En Caspe, siendo gobernador, Líster le propuso dar el paseo a los del Consejo regional de Aragón. Se opuso. "El juego era claro -me dice-. Los habría fusilado, y luego me habría echado la culpa a mí, presentándose como defensor de los proletarios".

El Ejército del Este está débil, dice, por falta de mandos. Que vaya a verlo. Me trae un folleto en lujoso papel que fabrican los soldados en una fábrica de que se ha incautado. Me pide permiso para reimprimir mis discursos, a fin de que los comisarios conferenciantes tengan un cuerpo de doctrina para sus pláticas. Se da el caso de algún comisario que da conferencias a la tropa sobre "Ulises y la guerra", o sobre "la civilización griega". Los medianamente instruidos se ríen. Los otros protestan ${ }^{45}$.

en La Pluma figuraba en singular: "la turbulencia...". El texto original de Azaña puede consultarse en el facsímil de La Pluma. Revista Literaria, Topos Verlag, Vaduz-Liechtenstein, 1980, t. 6, núm. 32, pp. 87-88. El artículo fue recopilado por Juan Marichal, sin mención de su procedencia, en el primer tomo de las Obras completas, Oasis, México, 1966, pp. 1091-1095 (el pasaje reproducido en Los Lunes... se encuentra en la p. 1094).

44 Recopilado en Manuel Azaña, Obras completas, ed. cit., t. 1, pp. 1095-1096.

45 Diarios completos. Monarquía, república, guerra civil, $2^{\mathrm{a}}$ ed., introd. S. Juliá, Crítica, Barcelona, 2004, p. 1247. 
El "folleto en lujoso papel" que menciona Azaña, bien pudiera ser, además del periódico El Combatiente del Este, la hoja semanal de Los Lunes... -recuérdese que su primer número es del 14 de noviembre de 1938 y que, al momento de la entrevista entre Mantecón y Azaña, se había hecho ya el segundo, del 21 de noviembre. Mantecón bien pudo, por tanto, solicitar también el texto o la autorización del presidente para reproducir una nota sobre literatura redactada por él.

Dada la fecha de aparición del número 9 de Los Lunes..., es casi seguro que ésta fue la última ocasión en la que Valle-Inclán fue homenajeado por los republicanos durante la guerra; pero, en cambio, no fue la primera. Cinco meses antes -el texto está datado el 1 de agosto de 1938- había sido recordado por uno de los escritores más admirados por el llamado "grupo de Hora de España" -y en especial durante los años de la guerra: "gran poeta de toda la juventud española", lo llama Altolaguirre en $1939^{46}$. Fue Antonio Machado el encargado de redactar el prólogo a una edición de La corte de los milagros que se imprimió bajo el sello "Nuestro Pueblo"47. Más que una presentación de la obra, se trata de una semblanza de Valle-Inclán, que comienza en el momento en que Machado lo conoció en Madrid y se detiene en aspectos que, a la luz de la guerra, connotaban una reflexión sobre la labor intelectual en tal circunstancia:

Él había preferido siempre -así nos lo confesaba- la espada a la pluma, y la profesión de literato, que, al fin, era la suya, le parecía un tanto subalterna para hombres de su laya.

A pura extravagancia achacaron muchos estas declaraciones de Don Ramón, pensando, no sin motivo, que sus hazañas ultramarinas, de coronel del ejército mejicano en Tierra Caliente eran

46 “Antonio Machado”, Nuestra España (La Habana), 1939, núm. 1; reproducido en Obras completas, ed. cit., p. 229.

47 Santos Martínez Sáura dice que este libro no llegó a distribuirse: "Y quien, además de Azaña, le rindió [a Valle-Inclán] de verdad un homenaje inolvidable, fue don Antonio Machado escribiendo en Barcelona, el 1 de agosto del 38, aquel prólogo para la edición de El Ruedo Ibérico que iba a haberse repartido entre los combatientes republicanos y, porque vinieron mal las cosas, sólo sirvió ya para que los de «la victoria» la quemasen juntamente con todos aquellos otros libros que tanto pavor causaban a quienes luego erigirían el monumento" (Espina, Lorca, Unamuno y Valle-Inclán en la política de su tiempo, $2^{a}$ ed., Ediciones Libertarias, Madrid, 1998, p. 354). E1 libro -que no es El ruedo ibérico completo sino su primera parte, La corte de los milagros- sin embargo, sí parece haber circulado, y es posible encontrarlo en algunos catálogos. 
más fantásticas que reales. De su talento de escritor, en cambio -ya había publicado su libro Femeninas-, nadie podía dudar. En efecto. Pero yo no dudaba tampoco de la honda sinceridad de sus palabras. Porque aquellas hazañas que él se complacía en relatarnos eran, en parte, al menos, imaginarias, mas no por culpa suya: él fue siempre muy capaz de todas ellas. Don Ramón, como Don Quijote, no conocía el miedo, o no había para él miedo que no superase por el espíritu, y estaba dotado de una enorme capacidad de resistencia para el sufrimiento físico ${ }^{48}$.

La relación entre Valle-Inclán y don Quijote era un tópico y ya había sido utilizada en los dos textos que le había dedicado al escritor gallego Manuel Azaña. La versión de un Valle-Inclán "quijotesco", a la vez, tanto para Azaña (quien subraya su intolerancia a la injusticia) como para Machado, trae aparejada una ética que incluso reconvierte la figura del bohemio, tan frecuente al describir a Valle-Inclán, en una suerte de asceta. Machado niega el estereotipo ("Nunca fue Don Ramón, ni aun en los tiempos de su mayor penuria, un bohemio a la manera desgarrada, maloliente y alcohólica de su tiempo") y propone una lectura moral del personaje:

De sus proezas imaginadas -las que él hubiera deseado realizar sacó don Ramón uno de los rasgos más atrayentes de su carácter y que más lo recomendaban a nuestra dilección. Don Ramón... tan literario, tan empapado en literatura, fue siempre mucho más que un literato. El capitán fracasado, no por su culpa, que llevaba consigo, proyectó acaso sobre toda su vida una cierta luz de heroísmo y abnegación militar, contribuyó en mucho a aquel sentido de consagración a su arte, como tarea ardua y espinosa que le distinguirá siempre entre sus coetáneos, por su capacidad de renunciación ante todas las comodidades del oficio, y por la inflexible lealtad a sus deberes de escritor. Como alguien nos refiriese el caso de un poeta, que, abandonando las faenas de su vocación, ponía su pluma al servicio de intereses bastardos, y se tratase de hallarle disculpa en la necesidad apremiante de ganarse el pan, don Ramón exclamó: Es un pobre diablo que no conoce la voluptuosidad del ayuno. ¡La voluptuosidad del ayuno! Reparad en esta magnífica frase de don Ramón, y decidme qué otra ironía hubiera proferido el capitán a quien se intima la rendición por

48 "Prólogo a La corte de los milagros, de Ramón del Valle Inclán", en Prosas completas, ed. O. Macrì, Espasa-Calpe-Fundación Antonio Machado, Madrid, 1989, t. 2, pp. 2266-2267. 
hambre de la fortaleza que, en trance desesperado, defiende (ibid., pp. 2267-2268).

Esta "voluptuosidad del ayuno", junto al rigor literario (la "total ruptura con el lugar común") lo llevaron a renunciar "a todas las ventajas materiales que se ofrecían entonces a las plumas mercenarias". Machado, así, concluye: "Desde este punto de mira - reparadlo bien- ningún escritor menos fascista que don Ramón María del Valle-Inclán” (p. 2268). El antifascismo de Valle-Inclán es el motivo con el que Machado concluye el prólogo:

Dos palabras para terminar. Don Ramón, a pesar de su fantástico marquesado de Bradomín, estaría hoy con nosotros, con cuantos sentimos y abrazamos la causa del pueblo. Sería muy difícil, ciertamente, que encontrase un partido del cual pudiera ser militante ortodoxo o que coincidiese exactamente con su ideario político. Pero, ante la invasión de España por el extranjero y la traición de casa, habría renacido en Don Ramón el capitán de nobles causas que llevaba dentro, y muchas de sus hazañas soñadas se hubieran convertido en realidades.

Los capitanes de nuestros días no tendrían ni amigo más sincero ni admirador más entusiasta que Don Ramón María del Valle-Inclán y Montenegro (p. 2271).

En el contexto de las apropiaciones de distintas figuras de la tradición literaria española que se inició con la guerra, el republicanismo de Valle-Inclán era bastante claro. Necesitaba, desde luego, ciertos matices. De allí la aclaración machadiana ("Sería muy difícil... que encontrase un partido del cual pudiera ser militante ortodoxo o que coincidiese exactamente con su ideario político"), muy en la línea de la que también sugiere, ya en 1923, Azaña: "Se sitúa, naturalmente, en la extrema oposición”. Y quizás, en efecto, el ser opositor haya sido el rasgo político más constante de Valle-Inclán. También ejercería la oposición, más allá de su colaboración como funcionario, durante la República -al punto de que en algunas ocasiones hizo declaraciones a favor de la necesidad de instalar una dictadura ${ }^{49}$. Uno

49 Dru Dougherty, en un importante estudio sobre ésta y otras cuestiones en torno a la relación de Valle-Inclán con la República, cita, por ejemplo, una entrevista publicada en el diario madrileño $E l$ Sol, el 20 de noviembre de 1931, en la que dice que "En España hay que hacer la revolución con la Dictadura. Se impone. Y no como la del pobre Primo, sino como la de Lenin”; sin embargo, en otra entrevista, aparecida en Luz el 9 de agosto de 1933, se 
de los episodios públicos de la primera mitad de década de los años treinta que mostró a Valle-Inclán como republicano, la negativa de la Academia de la Lengua (por entonces, en 1932, no era Real) a otorgarle el premio Fastenrath, es todavía recordado y aludido por Machado en su prólogo de 1938:

Lo cierto es que nuestro don Ramón tuvo hasta su vejez herméticamente cerradas las puertas de la Academia Española. Digamos, en su loor, que él nunca llamó a esas puertas ni, mucho menos, pretendió forzarlas. Sin embargo, ¡cuántos menos academizables que Valle-Inclán, y algunos aun en contra de sus propios deseos, penetramos por ellas! Él no fue nunca un enemigo sistemático de lo específicamente académico. Al contrario. Para él, más que para nadie, la lengua era materia inapreciable e instrumento precioso del arte literario. Muchos años de su vida había consagrado a conocerla, a manejarla, a enriquecerla, y hasta a pulirla. Todo cuanto se relacionaba con el lenguaje, desde la fonética hasta la semántica, le interesaba ${ }^{50}$.

El premio Fastenrath de 1932, en efecto, fue una suerte de batalla política, en la que los académicos quedaron tildados de "monárquicos" y Valle-Inclán de republicano. La opinión pública fue en gran medida afectada; la prensa derechista apoyó a los académicos, que no se dejaron influir por un candidato "del Gobierno", y periódicos liberales como Luz, Ahora o El Sol reclamaron por una reforma de la Academia, a la que vieron como una institución de antirrepublicanos. Cipriano Rivas Cheriff, por ejemplo, escribió:

los señores académicos han acordado declarar desierto el premio Fastenrath, que la opinión unánime daba por descontado para Valle-Inclán. ¿Por qué? Porque, aparte los indudables méritos literarios de una minoría entre los académicos, los demás están

declara "cerca de Mussolini”; son, además, muchas las veces en que se manifiesta contra el régimen parlamentario (Valle-Inclán y la Segunda República, Pre-Textos, Valencia, 1986, pp. 54 y 55). Los cargos públicos que Valle-Inclán ejerció durante la República fueron los de Conservador General del Tesoro Artístico Nacional, encargado de la realización del Museo de la República (que habría de instalarse en el Palacio Real de Madrid), entre 1931 y 1932, Director del Museo de Aranjuez en 1932 y Director de la Academia Española de Bellas Artes de Roma de 1933 a 1934. Fue además Presidente del Ateneo, sucediendo a Azaña, cuando éste asumió la presidencia del primer gobierno republicano.

50 "Prólogo a La corte de los milagros...”, p. 2270. 
allí con una representación social en franca rebeldía contra las instituciones republicanas y sus hombres representativos ${ }^{51}$.

En la serie de "desagravios" a Valle-Inclán que sucedieron al episodio, quizás habría que ubicar el artículo que Rafael Dieste publicó mucho más tarde, en marzo de 1935, en el número 3 de la revista P.A.N., titulado "Valle Inclán, premio Nobel". Se trata de una carta (la publicación se definía como "revista epistolar y de ensayos") fechada en Bruselas, el 28 de enero de 1935 -Dieste se encontraba allí como becario de la Junta para la Ampliación de Estudios-, dirigida a Otero Espasandín (director de la revista) y destinada a promover

Un premio para Valle Inclán, el premio Nóbel... Sería ilustre el premio, tendría o cobraría gracia heráldica, descifraría en acto de justicia natural su sentido, vendría a ser un signo de noble cortesía, valdría para él, bien limpia, la palabra Homenaje, si llamase a las puertas de Valle Inclán y fuese en sus umbrales presente y reverencia $^{52}$.

La postulación, en verdad, no era algo planeado por Dieste, sino un proyecto del grupo que constituía la revista o, más específicamente, de su hermano Eduardo, verdadero rector de su política editorial. Señala Arturo Casas que la carta de Rafael Dieste es "respuesta a la solicitud que le hace Eduardo Dieste cuatro días antes para que escribiese unas palabras que diesen a la candidatura algo más de viabilidad, al menos de puertas adentro en España" y que, más aún, "según informaciones epistolares posteriores parece ser que Valle conocía el proyecto de P.A.N. y que llegó a elogiar públicamente su rumbo en el curso de alguna intervención suya en el Ateneo"53. En verdad no es

51 El Sol, 21 de mayo de 1932, apud D. Dougherty, op. cit., p. 73 (véase, asimismo, en este trabajo, de donde tomo los datos recién mencionados, para un detenido relato del episodio, las pp. 72-78).

52 Cito por la reimpresión facsimilar: P.A.N. Revista Epistolary de Ensayos, pról. X.L. Axeitos, Ediciós do Castro, Sada, 1995, p. 45.

53 La teoría estética, teatral y literaria de Rafael Dieste, p. 315. Si Eduardo Dieste no ejercía la dirección nominal de la revista P.A.N. era debido a que tenía un cargo diplomático por el gobierno uruguayo. Una posdata en una carta de Rafael a Eduardo, del 4 de marzo de 1935, muestra que Eduardo habría manifestado reparos respecto de Otero Espasandín y que, en verdad, el "plan" de la revista era diseñado por los hermanos Dieste: "Política de P.A.N. -Espasandín está bien -en diálogo contigo- como director visible. Sus expansiones no creo que signifiquen riesgo para el plan de la revista y no 
tan extraño que supiese del proyecto, pues el grupo de P.A.N. se reunía en La Granja El Henar, el mismo sitio en donde ValleInclán tenía su tertulia ${ }^{54}$. Por lo demás, del carácter colectivo que tenía la candidatura propuesta por Dieste han quedado rastros en el cierre de la carta publicada: "Yo sé muy bien la lozanía íntima de cuanto os digo en esta carta, y que es bueno el metal; pero podéis darle otro giro si así conviene a vuestro alto propósito. Abrazos a toda la tripulación y para ti, caro Espasandín, de tu camarada Rafael Dieste"55.

En fin, la referencia a la Academia española, ya en la guerra, volvía a traer a colación una posición "republicana" de ValleInclán y, además, después del 18 de julio de 1936, hacía pensar en la situación actual de muchos académicos. El caso más llamativo, probablemente, por ser el de su director, fuera el de Ramón Menéndez Pidal, miembro de la Academia desde 1902 y su director desde 1925 (volvería a serlo en 1947):

está mal que influyan en su destino (siempre encauzadas por ti) pues trae, de cierta esfera de preocupaciones, una actitud muy sana. Y no hay peligro, insisto en esto. Es dócil -en el mejor sentido de la palabra-, aunque su docilidad tenga sus plazos. Por ahora está bien. Le escribiré. Creo que no habría inconveniente en mostrarle mi carta (la que te envié para él), diciéndole antes que me habías pedido escrito aludiendo a su opinión" (Obras completas. Epistolario, p. 64). Eduardo, incluso, debió haber consultado a Rafael por la conveniencia de ofrecer la dirección de la revista a María Zambrano, pues la misma posdata continúa: "María Zambrano. -No es devota de Ortega. Siente hacia él estimación personal, gratitud -incluso piedad (poniendo en esta palabra elevación de espíritu) pues cree que no está a la altura de sí mismo y que es una víctima de la perplejidad... Tiene, en suma, una actitud muy semejante a la nuestra -aunque teñida de afecto... Pero no me parece oportuno brindarle la dirección de P.A.N. Ella misma está a punto de caer en perplejidad... Estima de lejos -con honda nostalgia quizá- a los verdaderos P.A.N. Pero no se embarca... Está demasiado comprometida con cruces y rayas... -de buena fe... y sin fe. ¡No! La estimo en serio y digo: no” (ibid., pp. 64-65).

54 En su Crónica general, Juan Gil-Albert, que le dedica a Valle-Inclán un apartado del capítulo "Los maestros", cuenta que lo vio "en varias ocasiones... yendo o viniendo de la Granja El Henar" (Obra completa en prosa, t. 4: Crónica general, primera parte, Institución "Alfonso El Magnánimo"-Diputación Provincial de Valencia, 1983, p. 60). También Dru Dougherty, en su estudio ya citado, se refiere a la presencia de Valle-Inclán en esa tertulia.

55 P.A.N., p. 46. El saludo a la "tripulación" es una de las pocas pistas que pueden encontrarse en las páginas de la publicación sobre el sentido de la sigla que daba título a la revista, y que en 1935 permanecía oculto: Poetas Andantes Navegantes. 
He sabido que don Ramón Menéndez Pidal, a quien el ministro de Instrucción Pública sacó de Madrid poco menos que en andas (“¡cráneos privilegiados!”, que diría el pobre Valle-Inclán), no contento con pasarse a los rebeldes, ha dado en Nueva York, precisamente en la Casa de Italia, una conferencia sobre "La idea imperial de Carlos V”. ¡En la Casa de Italia, que está asolando imperialmente la tierra de don Ramón! Vergonzosa manera de formar en la murga ${ }^{56}$.

Ahora bien, el interés de la manera moral de entender la figura de Valle-Inclán que tiene Machado radica en que coincide con una característica también propia de Rafael Dieste. La nota que publica en Los Lunes..., de hecho, por momentos parece -más que la exégesis de los esperpentos de Valle-Inclán anunciada en el título- una reflexión sobre el heroísmo y el honor. Es claro que las circunstancias en que se publica este texto (finales de la guerra, una hoja literaria de un ejército) pueden haber incidido en ese sentido; sin embargo, el mismo tratamiento moral caracteriza otros textos diesteanos, anteriores y posteriores. A menos de un año de iniciada la guerra, en momentos menos apremiantes, y en una publicación menos "urgente", Dieste había dedicado un artículo a la "Hispanidad de ValleInclán" sobre el cual podría afirmarse lo mismo ${ }^{57}$.

Cabría pensar que, a pesar de haber sido escrito en momentos menos críticos de la guerra, el contexto, de todas formas, necesariamente afecta e imprime un sesgo ético a la lectura diesteana en 1937. Es probable, en efecto, que las circunstancias incrementen esa mirada; no obstante, es claro que hay de por sí en Dieste la tendencia a ese tipo de lectura. Ya en la nota de

56 Anotación de Manuel Azaña en su diario, 16 de noviembre de 1937 (Diarios completos, p. 1205). Ramón Menéndez Pidal fue director de la Real Academia Española de la Lengua desde 1925 a 1939 y, luego, de 1947 hasta su muerte, en 1968.

57 Hora de España, mayo de 1937, núm. 5, 27-34. El artículo, como su título indica, está sobre todo dedicado a desentrañar la "hispanidad" de Valle-Inclán y, por ello, parece en gran medida el despliegue de una frase de la nota de 1935: "Valle Inclán -pelea de la raza y el linaje, del ímpetu vital y la figura, ejemplo él mismo del más íntimo drama de la vida, ¡español!, ¡español!- clama y razona con los ojos quietos y anhela círculos perennes de razón divina; y varias curvas del impulso de su alma terrenal concluyen... ¡en teología!" (P.A.N., p. 45). Ya Arturo Casas ha dicho sobre este escrito que "nuestro autor introduce aquí ideas que desarrollará con más espacio en Hora de España un par de años más tarde" (op. cit., p. 315). 
1935 consideraba a Valle-Inclán "Platónico (y no del todo socrático) cuando razona su vida y su arte", pues

en el acto real (nativo y creador) de su hazaña literaria se remonta a las fuentes míticas del platonismo... antes de Platón: amor a la idea que aun es grávida figura en la más firme antigüedad de los antiguos, cuando la ética no había vaciado la virtud y las ideas no eran signo de recelo ante la mudable apariencia, negándole realidad, sino figuras perennes con que expresa la memoria su adoración y el alma su confianza ${ }^{58}$.

En el mismo ensayo, a la vez que reconoce esa ética en la que permanece la virtud, indica lo que, en términos de Dieste, parece casi su corolario: "Por eso en el mundo de Valle Inclán -testimonio de su límpida niñez antigua, que fue, sin duda, de granito y agua clara- tiene cada ser su escondido mandato y en la luz de sus actos descifra su blasón" (loc. cit.).

En "Hispanidad de Valle Inclán", a su vez, interpretaba las "criaturas" valleinclanescas -y sobre todo parece tener en mente las de sus esperpentos- como "máscaras" que sirven de amonestación al carácter personal y nacional ${ }^{59}$. Ante los "muñecos" de Valle-Inclán, de "caracterizadora y terrible inspiración española", hay que hacer "que la risa llegue al límite doloroso de la extrema burla":

En ese instante la marioneta valleinclanesca tendría que gemir, implorar. Tendríamos que gemir, implorarle. Y aunque no se hace - pues muchas cosas han de aplazarse hasta el Juicio Finalllevamos con nosotros, a partir de entonces, el peso de una fraternidad inevitable. Pero algún día esa dura fraternidad se enternece, y es cuando el prójimo del mecanismo vivo tiene en torno a sí la dilatada lividez del alba. Y hay que decirle: entra conmigo en esa luz, pues de otro modo no entraría yo íntegro, ni sería justo; y atribúyeme todo tu exceso de caracterización ante la luz del gran juicio. Pero vamos a entrar seriamente, quizá con gracia clownesca, sin pasaporte ni credenciales. Tira ese pergamino de justificaciones ${ }^{60}$.

58 P.A.N., p. 45.

59 Un interesante comentario de Arturo Casas interpreta este pasaje como una alegoría en la que Dieste opina sobre la división de los españoles durante la guerra (véase La teoría estética, teatral y literaria de Rafael Dieste, pp. 458-459)

60 Hora de España, núm. 5, 31-32; y Testimonios y homenajes, p. 127. ArTuro Casas ha apuntado que Dieste tiene aquí, en lo relativo a la idea del clown 
Esta suerte de sátira que Dieste observa en los esperpentos -que no oculta "cuánto amor y qué áspera firmeza hay en las burlas de Valle Inclán"61_ conlleva, como se dijo, una implícita amonestación, una moral. Justamente, este aspecto es subrayado en la segunda parte de la nota de Los Lunes... El escrito, grosso modo, parece estructurado en dos secciones que lo dividen en mitades: la primera consiste en una reflexión sobre el sentido del heroísmo y del honor (quizás no tanto en Valle-Inclán como en Dieste mismo); la segunda en una explicación de los ejemplos negativos que pueden encontrarse en Martes de carnaval-casos, si se quiere, de la ética sin virtud. En la segunda parte, entonces, recurre a personajes de Las galas del difunto, Los cuernos de don Friolera y La hija del capitán para criticar actitudes cuya actualidad no es difícil de percibir. Así, Juanito Ventolera encarna los riesgos de que el "buen sentido de fuente popular" sea tergiversado por "la fanfarronería que aprendió de sus jefes en la guerra de Cuba". Él, tanto como don Friolera, muestra el peligro de un sentido "retórico" del honor. La bravuconada, la exigencia de respeto, son formas de la apariencia que nada tienen que ver con el valor ni con el heróísmo. Otro tanto sucede con las protestas de patriotismo; la jactancia vacua suele ser acompañada del afán de "pisotear" al prójimo y, por tanto, "Lo «faccioso» está aquí, desaforado y al desnudo, sin ninguna exageración, como al fin hemos visto". Desde luego, los esperpentos de Martes de carnaval ya de por sí remiten al mundo castrense y permiten establecer una distinción moral entre los militares que Valle-Inclán presenta y los milicianos que defienden la República. Por tratarse de una diferencia ética, el heroísmo y el valor de los milicianos han de ser de un carácter diferente a los de los rebeldes. El heroísmo, definido como "la virtud humana para hacer las cosas bien" debe respaldarse en la comunidad, tener su fuente en "los inocentes": "frente al peligro y al misterio, se fortifica -y es natural- en la gratitud de todos y con la devoción de los inocentes"; el héroe verdadero así lo necesita "para restituir su fuerza a la comunidad de voluntades que le anima y no quedar terriblemente aprisionado en esa fuerza como en cosa

inglés, "muy presente el Juan de Mairena que dos meses antes había reseñado en este mismo medio [Hora de España, núm. 3]" (op. cit., p. 458, n. 130). En efecto, véase, en relación con este artículo, el quinto segmento del cap. 23 del libro machadiano de 1936 (Juan de Mairena I, $5^{\mathrm{a}}$ ed., ed. A. Fernández Ferrer, Cátedra, Madrid, 2003, p. 198).

61 Hora de España, núm. 5, p. 34; y Testimonios y homenajes, p. 131. 
suya", pues de otro modo sería un remedo, un ornamento sin sustancia. El verdadero heroísmo, en fin, tiene su fundamento en la inocencia, que "no se hace ni se deshace: se pierde o se gana, y aun vuelve -ya perdida- cuando el hombre está de veras anhelando ser otra vez limpio y dejar lastre de soberbia. Y no hay simulación que valga en esa esfera, ni importa el espectáculo". Encontramos aquí ecos de un texto de Juan de Mairena, que Machado había publicado en Hora de España en marzo de 1937:

Os confieso mi poca simpatía por los boxeadores americanos. Hay algo en ellos que revela la perfecta ñoñez de las luchas superfluas a que se consagran y es la indefectible jactancia previa de la victoria. Si interrogáis a Johnson en víspera de combate, Johnson os dirá que su triunfo sobre Dewey es seguro. Si interrogáis a Dewey, Dewey no vacilará en contestar que Johnson es pan comido. Y yo desearía un juez de campo tan hercúleo que fuese capaz de coger a Johnson y a Dewey y de aplicarles una buena docena de azotes en el trasero. ¿Qué falta de respeto al adversario! Y sobre todo ¡qué falta de modestia! ¡Cómo se ve que esas luchas, no siempre incruentas, tan del gusto de los papanatas, no pueden contener un átomo de heroísmo! Porque lo propio de todo noble luchador no es nunca la seguridad del triunfo, sino el anhelo ferviente de merecerlo, el cual lleva implícita -¿cómo no?- la desconfianza de lograrlo ${ }^{62}$.

Tanto para Machado como para Dieste el combate debe estar regido por una conducta moral que haga a quien lucha merecedor de la victoria. Así debe ser. Pero en la España que denuncian los esperpentos, "lo heroico... era cosa de oficio y de ornamento" y "el honor vino a ser código de fatuos", de allí que la antigua esperanza de Valle-Inclán, en los héroes y en los inocentes, se le fuera convirtiendo en cólera. Es en Luces de bohemia en "donde se ve cómo se quiebra la esperanza que al principio decíamos, cómo se encrespa ante esa oquedad pretenciosa que invadía las letras -e incluso descendía al pueblo- un poeta que rueda entre los «émulos»".

Llama la atención que, en enero de 1939, Dieste escriba que esa muerte, la de Max Estrella, "tiene un gran horizonte de amanecer donde otra vez comienza España”, pero algo frena su propia esperanza, cuando las "congojas y ansiedades" que la

62 "Sigue hablando Mairena a sus alumnos", Hora de España, marzo de 1937, núm. 3, p. 6; también en Juan de Mairena II (1936-1938), 4ª ed., ed. A. Fernández Ferrer, Cátedra, Madrid, 2002, p. 26. 
imagen le trae, le "aconsejan silencio". El final del escrito, algo ambiguo, incluso apresurado, recurre a la máxima, a la afirmación que busca fortalecer una virtud: "Si eres soldado recuerda esa muerte, pues fortifica mucho llevar la muerte de un poeta así cerca del corazón".

En este texto, como en los demás que Dieste escribió sobre Valle-Inclán, queda implícita la idea de que la moral que se lee en la obra tiene, a modo de bóveda que la ampara y la guía, la moral de su autor. También en el pasaje antes citado de "Hispanidad de Valle-Inclán” (el escrito más cercano, y no sólo temporalmente, al que se publicó en 1939) se manifiesta un vínculo estrecho entre lo representado y lo extraliterario: lo que atañe al autor e incluso lo social (más específicamente, en este caso, lo nacional). En efecto, esta idea de reflejos que remiten de una instancia a otra se encuentra en Dieste y puede verse no sólo a lo largo de ese mismo artículo sino en un texto posterior. Se trata de una conferencia dictada en Montevideo, en el paraninfo de la Universidad, y de la que sólo disponemos de un resumen recogido y publicado por Esther de Cáceres en el diario El País, el 4 de noviembre de 1948 -si bien, en alguna medida, "refrendado" por el propio Dieste, que lo reúne con otros textos críticos en Testimonios y homenajes. En esa conferencia, según la glosa de Esther de Cáceres, señala Dieste que "Valle Inclán se mantuvo fiel, siempre, al vínculo perfecto de la persona total, angélica y pecadora, y el poeta. Jamás pudo pensar Valle Inclán que la persona y el poeta fueran dos cosas; y no pudo hacer divisiones en su ser, encomendando el vuelo al poeta y el pecado al hombre"63.

En esta conferencia se encuentra el caso quizás más explícito de una lectura "ética" de la obra valle-inclaniana:

Terminó, luego, Dieste, su conferencia diciendo que otro de los aspectos interesantes de Valle Inclán era el de su ética. A primera vista parecía un buen señor a quien tanto le daba la moral; y, en el sentido corriente de la moral, Valle Inclán no era un moralista. Pero Valle Inclán tenía una ética profunda, y uno de los secretos de su eficacia psicológica consistía en poseer, justamente, una ética firmísima, no formal. Era una ética señorial. Tal ética señorial no significaba el desprecio o la altivez, sino que, para Valle Inclán, lo señorial era una especie de estado culminante desde el cual se podía comprender y cobijar a los demás. Entonces, si Valle Inclán

63 "Resumen de «Una semblanza espiritual de Valle Inclán»", en Testimonios y homenajes, p. 211. 
tenía, por momentos, una sorprendente lucidez como psicólogo, era porque tenía una ética profunda, porque ésta era, a su vez, una ética viva, y porque era una ética señorial. Ahora, esta ética señorial dejaría de serlo, si Valle Inclán pretendiera comprenderlo y cobijarlo todo, pues entonces de señor pasaría a ser demonio. Y el límite, se lo ponía el propio Valle Inclán cuando no comprendía a nadie; pedía, entonces, perdón a todos, y era el momento en que hablaba de Jesús y de San Francisco (ibid., p. 216).

La integridad, la identidad del sentido moral que tienen el autor y sus obras (no sólo las escritas) es aquello que Dieste ha querido a menudo subrayar en Valle-Inclán, un escritor tan independiente frente a los partidos políticos y las facciones como fue el propio Dieste. En enero de 1939, a pocas semanas de salir de España a un exilio cuya duración nadie podía por entonces imaginar, no es extraño que leyera en los esperpentos la cólera surgida de una "antigua esperanza" frustrada. Por lo demás, la muerte de Max Estrella, recordada en el último párrafo publicado por Dieste en suelo republicano, mientras se derrumbaba la resistencia en Cataluña, adquiere la fuerza de una imagen inquietante.

Las circunstancias, desde luego, no favorecían la calma. Sin embargo, este texto de Rafael Dieste manifiesta una serenidad en la reflexión que lo convierte en un testimonio más de la ética y de la estética -una y otra entrelazadas- que siempre defendió; una ética-estética que puede verse en sus escritos, pero también en sus acciones. El ejemplo más cercano al final de la guerra lo ha narrado uno de sus compañeros. Juan Gil-Albert, en sus Memorabilia, ha contado una anécdota ocurrida en el campo de concentración de Saint Cyprien que, a partir de su relato, se ha hecho relativamente conocida ${ }^{64}$. El suceso, descrito en la prosa

64 De hecho, años después, Antonio Sánchez BARbudo, al dar su versión del episodio, la presenta como una suerte de rectificación de la de GilAlbert, reconvirtiendo el "episodio cervantino" en "escena cómico-patética": "Rafael Dieste, como todo el mundo, hablaba y actuaba de diversos modos según la ocasión, claro es. Mas diríase que en cualquier circunstancia él era más fiel a sí mismo, más constante en su especial manera de ser que la mayoría de los mortales. Su discurso brotaba con noble intención y exquisito lenguaje -aunque fuese con ira-incluso cuando iba dirigido a un auditorio hostil y poco dispuesto a elevarse a grandezas. Y esto dio lugar a veces a ciertas escenas algo cómico-patéticas. Una de éstas ocurrió una de las últimas noches que pasamos en Saint-Cyprien. Juan Gil-Albert recuerda, en las dos últimas páginas de su Memorabilia, ése que él llama «episodio cervantino». Lo que éste escribe es bueno, divertido; pero aunque nombra a Dieste, no se 
cuidada que lo caracteriza, cierra el libro (acaso porque, como dice, "por años que viviese, no lo olvidaría nunca") y ocurre luego de una larga tormenta de viento que soportan los refugiados. Al fondo del campo -según indica Gil-Albert- se habían levantado unas casetas muy precarias para el Estado Mayor, a las que el grupo (en el que estaban Dieste, Gaya, Sánchez Barbudo), por formar parte del Comisariado, pudo trasladarse. Al vendaval, frente al cual la techumbre era de poca ayuda, se sumó la lluvia, para la que sí servía. De allí que la gente, pretendiendo entrar para cobijarse, fuese acudiendo a las construcciones. Pero "la capacidad de cabida estaba de tal manera rebasada... que ni un solo hombre podía ya aspirar a convertirse en los de dentro, que habían aumentado pero continuaban siendo una minoría"65. Algunos de los que estaban dentro, en la penumbra, trataron de "pronunciar arengas que resultaban, a pesar de su vibración forzada, mohínas y vacuas", pues "se pretendía explicar lo inexplicable, hacer tragar un anzuelo sin nada que masticar". Y así, "palabrotas e insultos caían, como piedras, sobre las cabezas, invisibles, de los oradores-fantasmas" 66 .

"Entonces -sigue Gil-Albert- fue cuando Dieste se puso a hablar". La descripción del orador, el relato de la situación -que recuerdan un episodio ocurrido en Cáceres, durante una de las misiones pedagógicas de $1934^{67}$ - componen el retrato de alguien muy lejano de los modos casi "épicos", a menudo altisonantes, de gran parte de la retórica de la guerra:

entiende bien con su relato qué es lo que realmente sucedió" ("Rafael Dieste, el elocuente y genial amigo", Documentos A, enero de 1991, núm. 1, p. 29).

65 Op. cit., p. 191.

66 Ibid., p. 192. En la versión de Sánchez Barbudo, en cambio, "Lo que pasó es lo siguiente: como dormíamos tumbados en la arena, sin más techo que el cielo, recogimos con avidez las tablas que, al fin, entregaron a nuestro grupo, pues ellas iban a ser la base de nuestra futura tienda de campaña. No las perdíamos nunca de vista durante el día, y en la noche nos acostábamos cerca de ellas. Pues bien, una noche oí ruido, voces, y al despertarme me di cuenta de que unos seres extraños estaban llevándose nuestros tablones. Me levanté y empecé a gritar y a gesticular pidiendo ayuda, pero nadie parecía muy dispuesto a enfrentarse con los ladrones. Fue entonces, mientras trataba yo en vano de sujetar a uno, cuando vi a mi lado a Dieste... Apoyó firmemente la mano en el hombro de un soldado no muy fornido que sostenía con sus dos brazos la tabla, y empezó a soltarle con voz fuerte un enérgico discurso de condenación" (loc. cit.).

67 Véase la narración del episodio en Eugenio Otero Urtaza, Las misiones pedagógicas: una experiencia de educación popular, Ediciós do Castro, Sada, 1982, pp. 105-106. 
Su entonación no estaba hecha para las grandes asambleas, ni el metal de su voz, que no podía evitar el que se configurara en mi imaginación, allí, a dos pasos, velado por la tiniebla, su fino rostro levemente ascético. El despropósito mismo que animaba su intervención actuó de incentivo, y, la verdad es que, por unos momentos, la gritería calló y el silencio se hizo. Rafael dijo algo que, en sustancia, y en estilo, podía parangonarse así: "Nada más justo que vuestra protesta, camaradas, pero nada más injusto que vuestra ira. ¿Dónde está aquí el enemigo y a quién agredir? Es inexistente. Todos somos uno; no una mesnada que se pelea por el reparto de un botín sino la expresión de un pueblo afligido que, pese a las circunstancias malaventuradas, no ha perdido la fe ni el decoro. Somos los españoles. Lo que lleva en sí una exigencia de comportamiento que es, hoy por hoy, lo único que poseemos, nuestro único bien. Y no podemos entregarnos a unas disputas triviales que nos deshonran. Fijaros bien: estar aquí dentro no supone la usurpación de un derecho, es una situación casual: unos habían de ser los primeros mientras la enmienda de este estado insoportable pero provisional continúa. Y hemos sido nosotros, pero intercambiables como vais a ver. Yo me salgo y otro entra en mi lugar... Si es que puedo porque, camaradas, estamos emparedados, y la falta de movimiento nos tiene aquí tan incómodos, como ahí, a vosotros, la lluvia, os tiene coléricos. Venga, dejadme salir...". Y un murmullo de expectación se hizo notar como siempre que una situación desconcertante pone a la colectividad humana en manos de su decisión propia, sin un modelo fijo al que obedecer. Por fin, de lejos, oímos que alguien aventuró con un dejo personal que resumía, seguramente, la tónica, informe, del auditorio: "Lo que tú eres es un... raro". Así, con esa pausa que valoraba el hallazgo del término, de la palabra buscada, de la propicia, de la definitoria. Y el prorrumpir de unas risas ${ }^{68}$.

Y así, como tantas veces a Valle-Inclán, le tocará ahora a Rafael Dieste, en la prosa de Juan Gil-Albert, ser visto como don

68 Op. cit., pp. 192-193. Por su parte, Sánchez Barbudo glosa brevemente el discurso de Dieste, "que venía a ser, en substancia, algo como que era bien triste, una vergüenza, que los que habían sido camaradas y habían luchado por una causa justa, ahora, vencidos, se comportaran como bellacos y trataran de robar a sus compañeros, y que la derrota no tenía que convertirnos en seres degradados, envilecidos. No sé cuánto de todo aquello dicho con voz clamante sería entendido, pero algo debió calar en el ladronzuelo, pues de pronto soltó la tabla, y con un gesto que era a la vez de extrañeza, fatiga y disgusto, exclamó, mirando a Rafael cara a cara: «Lo que tú eres es un... raro». (Esto en la versión de Gil-Albert, aunque lo que yo creo que dijo fue «un tío raro»)" (loc. cit.). 
Quijote, como un clásico -con su estampa, sus maneras- en un campo de concentración:

Fue, para mí, como la visión penetrante de una realidad que recordaba, una escena vieja de nuestro patrimonio que se hubiera personificado de nuevo, algo así como si estuviera asistiendo a la modernidad perenne de lo clásico: los mismos factores, el mismo drama, lo irredento del cuadro, la voz delicada del hombre, cargado de razones, el altisonante gesto inútil, el exabrupto vital que cala hasta los huesos, la comicidad: "Podrán los encantadores quitarme la ventura pero el esfuerzo y el ánimo será imposible”. Sí, acababa de ver, de reconocer, de oír -con un regocijo preñado de congoja- ¿a quién? Y no sé por qué coincidencia de las llamadas providenciales, la lluvia cesó, y los ánimos, calmados, dieron fin, por el momento, sin más consecuencias, como sucede con las tormentas que espantan y amainan después, a este, sonámbulo, episodio cervantino. Pero que no conviene echar en saco roto ${ }^{69}$.

Y en efecto, la escena forma parte de "nuestro patrimonio". No sólo por la reminiscencia literaria, sino también por la repetida imagen de una persona intentando mantener la dignidad en las circunstancias menos favorables. No es esto heroísmo. Como dice Mairena del humilde torero que opone a la jactancia de Johnson y Dewey, "quien habla así, podrá no ser un héroe, pero no es un bruto"70. Lo que de quijotesco pueda verse en ello quizás dice más de los tiempos que de las personas.

Así, antes y después de 1939, incluyendo su paso por Saint Cyprien, las dos largas décadas de su exilio y el regreso a una España que permanecía en penumbras, Dieste mantendrá una conducta que ni excluye la voluntad de diálogo y de comprensión de las posiciones ajenas, ni prescinde de la necesidad de defender y sostener las posturas y decisiones propias. Y esas decisiones, esas posturas, son tanto literarias como políticas. Son, en fin, una ética. Algo que, desde luego, "no conviene echar en saco roto".

CÉSAR A. NúÑez

Universidad Autónoma Metropolitana-Iztapalapa

69 Ibid., p. 193. La frase citada, "Bien podrán los encantadores quitarme la ventura, pero el esfuerzo y el ánimo será imposible”, corresponde al cap. 17 de la Segunda parte del Quijote (en la ed. llamada "del IV Centenario", auspiciada por la RAE-Alfaguara, Madrid, 2004, p. 677).

70 Hora de España, núm. 3, p. 7; y Juan de Mairena II (1936-1938), pp. 26-27. 


\section{ANEXO}

Reproduzco a continuación el escrito de Rafael Dieste. Solamente he corregido unas poquísimas erratas ("restitur" por "restituir", "reir" por "reir", "handa" por "anda") $e$ introducido minimas variantes de acentos (reemplazando "vió como" por "vio cómo", "dió" por "dio" y, en el último párrafo, restituyendo las tildes en "se ve cómo se quiebra ...., cómo se encrespa...”). Por lo demás, transcribo el texto tal cual aparece en el original.

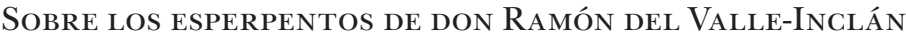

Escribió don Ramón los Esperpentos cuando orillaba la vejez y una antigua esperanza se le estaba convirtiendo en cólera.

Él creía en los héroes y en los inocentes. A estos los veía en los campos, y amaba en ellos, con rendida fortaleza, esa gracia de espíritu parecida al descuido de los árboles. Y también los hallaba en los bordes y remolinos de la gran ciudad, como traídos y llevados por esa historia que no está en las historias, y que se allanaba en coloquios o en silencio para sentirlos pasar sobre su alma, entonces más que nunca menudamente florecida. Era esa gracia que no busca imponerse, y que es tal vez la más grande -pues toda verdadera grandeza se le rinde- lo que le congracia con el mundo.

Y he aquí lo que pasaba con los héroes. La inocencia, en realidad de verdad, no se hace ni se deshace: se pierde o se gana, y aun vuelve -ya perdida- cuando el hombre está de veras anhelando ser otra vez limpio y dejar lastre de soberbia. Y no hay simulación que valga en esa esfera, ni importa el espectáculo. En cambio el heroísmo, que es la virtud humana para hacer las cosas bien, frente al peligro y al misterio, se fortifica -y es natural- en la gratitud de todos y con la devoción de los inocentes; y así, además lo necesita el héroe para restituir su fuerza a la comunidad de voluntades que le anima y no quedar terriblemente aprisionado en esa fuerza como en cosa suya. Así es, cuando es de veras todo esto. Pero en aquel punto de los homenajes y del regalo que hay que hacer al héroe, comienza el riego de la emulación y de ardides inicuos que todo lo trastornan. Y si al fin sólo queda el disputar por fueros y galas imponentes, todo lo humano se marchita, el hombre no se reconoce en el hombre, o sólo reconoce en otro su propio vacío, la verdadera plenitud deja el sitio a lo hinchado y el amor a las cosas que han de ser asistidas por nuestra lealtad para que nazcan en sazón, viene a parecer desvarío de ilusos o arrebato de gente díscola y desaforada. Porque ya sólo importan los fueros y su brillo.

Y en cuanto al honor, que en buen entender es el respeto al fundamento de lo convenido, pierde intimidad, se convierte en convenio sin fundamento alguno y termina en disloque y mascarada.

Así, el otro amor de don Ramón -un viejo hidalgo de Galicia que en mocedad anduvo indeciso entre las armas y las letras, hasta que vio cómo el valor está en el justo empleo de las armas o las letras que se tienen y en no sacarlas a relucir de cualquier modo- el otro amor, decimos, estaba muy desconcertado y ya con ganas de reír a lo macabro. Pues lo heroico de España era cosa de oficio y de ornamento: y otras virtudes semejantes -todo lo pro- 
pio del varón en tránsitos decisivos y en cimas de responsabilidad- corrían la misma suerte. Es decir, faltaban allí donde eran más urgentes, pero no, en cambio, el afán de monopolizar sus apariencias y los correspondientes privilegios. Andaban de cabeza las palabras. El honor vino a ser código de fatuos. La vaciedad armada - pues era la gente de armas la más atacada de esos males- se ensoberbecía con pretensiones de orbe nacional. "¡España somos nosotros! ¡Arriba España!...” Es decir: ¡Boca abajo todo el mundo! Así, esos bravos -espantosamente antipatriotas, pues quien tiene patria de veras es reverente hasta el fin y no anda pisoteándolo todo con sus fueros y con su manía de emulación- no parecían tener otro destino que el de dejar a España inerme, si bien decían "patria" con la voz quebrada o cavernosa, según los temperamentos pero siempre ensublimecida para armarse de retórica. Quizá también por mimetismo o repitiendo un estribillo escolar, pues - no cabe duda- en todo eso había mucho de tontería.

Todo lo cual llegaba a trastornar la cabeza de los humildes, que en viendo aquello, volvían de la "mili" como Juanito Ventolera. En él, si os fijáis, descubriréis un buen sentido de fuente popular cruzado con la fanfarronería que aprendió de sus jefes en la guerra de Cuba. El fanfarrón no se enamora, sino que burla a las mujeres por apuesta. Se enfrenta con Dios, creyéndolo inofensivo - pues cree en él a su manera, interpretándolo como la Suma Tolerancia- y así blasfema en hueco para asustar a los amigos, pero se encoge ante un sargento o ante un escribiente de "Mayoría". Le faltaría al respeto a su madre por apuesta, si no estuviese establecido en el retórico honor del fanfarrón el respeto a la madre, a una madre de novelas por entregas. Y así le veréis ponerse las galas de un difunto para ganar prestigio ante sus compinches y lucirse ante una moza del partido. Ni cuando ve que la moza es hija del muerto, no cede en su papel de hombrazo que no teme a los muertos. Sin supersticiones no habría tales bravos, que hacen del valor una superstición más -una superstición cobarde, pues creen que, puesto que un muerto no es temible, no hay por que respetarlo. ¿Qué locura! No obstante no dejará de inspirarnos una vaga simpatía ese Juanito Ventolera, porque, en el fondo, más que un fanfarrón parece ser un zafio puesto a burlarse de la fanfarronería. Representa el papel de sus jefes y quizá sabe que lo representa. Pero hay que andarse con cuidado con esas representaciones. Y si encontráis a Juanito Ventolera no estará de más que le peguéis un susto serio.

Nos encontraremos con la ambigua historia de don Friolera. ¡Pobre don Friolera! No es menos bravo que aquellos oficiales que se reúnen para obligarle a vengar afrentas y a despojarse de cuernos por "espíritu de cuerpo". Quizás es menos superficial y, sin embargo, es ridículo, porque un ciclón de mentiras le mueve como a un espantapájaros y no puede ver su auténtica desventura. A veces ésta se trasluce, y es terrible ver en el fondo de un viejo aquel afán de reposo, que no es cobarde, sino inocente y natural en él. Doña Loreta no es una novelera y Pachequín, el seductor, hace ondear su retórica sin que falte nada: pasión, caballerosidad y frases célebres. El pobre don Friolera dio la debida satisfacción al espíritu de cuerpo ateniéndose a la letra de los cuernos y de las ordenanzas. Todo esto es muy equívoco. Andan mezcladas muchas cosas. Pero don Ramón une aquí el tacto más delicado a la más cruda violencia de los altibajos. 
Vemos luego en la Hija del Capitán cómo aquel fanfarrón espíritu de cuerpo está dispuesto a pisotearlo todo con frases patrióticas. Lo "faccioso" está aquí, desaforado y al desnudo, sin ninguna exageración, como al fin hemos visto. Por último, "Luces de Bohemia", donde se ve cómo se quiebra la esperanza que al principio decíamos, cómo se encrespa ante esa oquedad pretenciosa que invadía las letras -e incluso descendía al pueblo- un poeta que rueda entre los "émulos". Le veréis morir. Y ahora no digo más, porque esa muerte tiene un gran horizonte de amanecer donde otra vez comienza España, y se cruzan en ella congojas y ansiedades que sin otra razón que la instantánea de haber venido a acometerme ahora, me aconsejan silencio. Si eres soldado recuerda esa muerte, pues fortifica mucho llevar la muerte de un poeta así cerca del corazón.

Rafael Dieste 